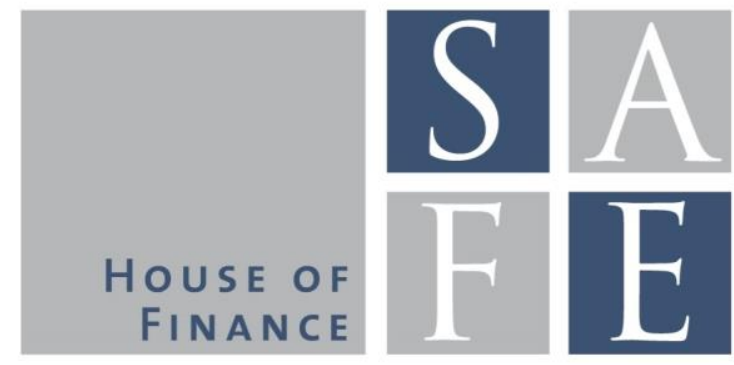

WORKING PAPER SERIES

Tobias H. Tröger

\title{
Regulation of Crowdfunding in Germany
}

SAFE Working Paper No. 199

SAFE I Sustainable Architecture for Finance in Europe A cooperation of the Center for Financial Studies and Goethe University Frankfurt 


\title{
Regulation of Crowdfunding in Ger- many
}

\author{
A Critical Assessment of the Bail-in Tool under the European Bank Recovery and \\ Resolution Regime
}

(February 4, 2017)

Tobias H. Tröger

Professor of Private Law, Trade and Business Law, Jurisprudence Goethe-University, Frankfurt am Main, Department of Law

Theodor-W.-Adorno Platz 3

60629 Frankfurt am Main

Germany

Phone +496979834236

Fax +496979834536

troeger@jur.uni-frankfurt.de

\begin{abstract}
This paper is the national report for Germany prepared for the to the $20^{\text {th }}$ General Congress of the International Academy of Comparative Law 2018 and gives an overview of the regulation of crowdfunding in Germany and the typical design of crowdfunding campaigns under this legal framework. After a brief survey of market data, it delineates the classification of crowdfunding transactions in German contract law and their treatment under the applicable conflict of laws regime. It then turns to the relevant rules in prudential banking regulation and capital market law. It highlights disclosure requirements that flow from both contractual obligations of the initiators of campaigns vis-à-vis contributors and securities regulation (prospectus regime). After sketching the most important duties of the parties involved in crowdfunding, the report also looks at the key features of the respective transactions' tax treatment.
\end{abstract}

Keywords: G23, G28, G38, K22, K23.

JEL classification: crowdfunding, crowdsponsoring, crowdlending, crowdinvesting, contract law, conflict of laws, banking regulation, securities regulation 


\title{
Regulation of Crowdfunding in Germany
}

\author{
- Tobias H. Tröger* -
}

\section{Introduction}

\subsection{Policy objectives}

Crowdfunding is a buzzword that signifies a sub-set in the new forms of finance facilitated by advances in information technology, usually categorized as fintech. ${ }^{1}$ In contrast to financial innovation that pertains to (new or redesigned) financial products and is somewhat ambiguous in its social value, ${ }^{2}$ crowdfunding capitalizes on previously unavailable digital techniques to match supply and demand on money and capital markets. These developments potentially disrupt traditional forms of intermediation by shifting the boundaries of the (financial) firm. ${ }^{3}$ Put differently, crowdfunding does not typically lead to unprecedented forms of financing relations. Instead, it enables that traditional contractual or corporate law relationships between previously unacquainted providers and consumers of capital are initiated and concluded on novel, IT-driven platforms. From this vantage, the potential of crowdfunding to garner economically significant volumes of financing relationships seems indeed considerable, ${ }^{4}$ thereby creating massive potential for momentous disruption as a consequence of disintermediation.

${ }^{*}$ Professor of Private Law, Trade and Business Law, Jurisprudence, Goethe University Frankfurt am Main, Program Director Research Center Sustainable Architecture for Finance in Europe (SAFE). Associated Professor Institute of Monetary and Financial Stability (IMFS). The author gratefully acknowledges financial support of the LOEWE Research Center SAFE.

${ }^{1}$ On fintech in particular Dirk A. Zetzsche et al., From FinTech to TechFin: The Regulatory Challenges of Data-Driven Finance (European Banking Inst. (EBI) Working Paper No. 6, 2017), https://ssrn.com/abstract=2959925.

${ }^{2}$ For proposals that seek to hedge financial stability against regulatory arbitrage without sacrificing the efficiency enhancing potential of financial innovation see Eric Posner \& E. Glen Weyl, An FDA for Financial Innovation: Applying the Insurable Interest Doctrine to 21st Century Financial Markets, 107 NW. U. L. REV. 1307 (2013) (arguing for pre-screening of financial innovations through a Federal Drug Authority like agency); Tobias H. Tröger, How Special Are They? Targeting Systemic Risk by Regulating Shadow Banks, in RESHAPING MARKETS. ECONOMic GovernANCE AND LIBERAL UtOPIA 185-207 (Bertram Lomfeld, Alessandro Somma \& Peer Zumbansen (eds.), 2016) (showing how a normative approach to law enforcement allowed existing prudential regulation to capture regulatory arbitrage). For an overview of the regulatory challenges non-bank banks pose with regard to systemic risk Eddy Wymeersch, Shadow Banking and Systemic Risk (EBI Working Paper No. 1, 2017), https://ssrn.com/abstract $=2912161$.

${ }^{3}$ The extent to which allocation of resources occurs in a hierarchy (firm) depends on the transaction costs incurred in equivalent market transactions, for the fundamental insight Ronald $\mathrm{H}$. Coase, The Nature of the Firm, 4 ECONOMICA 386 (1937); for a review of the literature carrying forward the theory of the firm see EIRIK G. FURUBOtN \& RUdOLF RICHTER, INSTITUTIONS AND ECONOMIC THEORY 366-86 (2d ed., 2005). With regard to financial intermediation this means that market based solutions should become more prominent once the comparative advantages of intermediation within a big entity shrink, which is particularly the case if search costs are lowered as a function of technological improvements.

${ }^{4}$ The early literature points to crowdinvesting's potential to allow firms to receive financing from an additional source that complements bank and venture capital funding, Nikki D. Pope, Crowdfunding Microstartups: It's Time for the Securities and Exchange Commission to Approve a Small Offering Exemption, $13 \mathrm{U}$. PA. J. Bus. L. 101, 113 (2011); MacLeod Heminway \& Shelden Ryan Hoffman, Proceed at Your Peril: Crowdfunding and the Securities Act of 1933, 78 TENN. L. REV. 879, 931 (2011); C. Steven Bradford, Crowdfunding and the Federal 
Once these projected developments gain traction, policy objectives traditionally pursued in financial regulation also become relevant for agents involved in crowdfunding. ${ }^{5}$ Concerns for financial stability, investor and consumer protection, or the prevention of money laundering and funding of terrorism hinge incrementally on including the new techniques to initiate financing relationships adequately in the regulatory framework. More specifically, the legislation through which policy makers seek to implement the relevant objectives, ceteris paribus, have to be attentive to the specifics of crowdfunding.

Taken together with the aforesaid, the pertinent legislation has to pay particular attention to the role of the platforms and their operators because they are at the heart of the technological innovation, which - at the same time - may both attenuate traditional justifications for government intervention and create new jeopardies for established policy goals. On the other hand, the laws that govern the relevant financing relationships once they are concluded face far less challenges insofar as they are not materially affected by the way relationships are initiated and concluded. Put differently, the contract or corporate law framework that underpins financing relationship is old fashioned, but the way it is invoked is novel.

\subsection{Economic relevance of crowdfunding in Germany}

The available data largely pertains to the forms of crowdfunding (see infra 1.2 and 1.3) that initiate classical financing relationships (loan contracts; purchase of debt instruments or equity interests). Granular data on funding relationships with significant altruistic elements is largely lacking. ${ }^{6}$

\subsubsection{Crowdlending/peer to peer (P2P) lending}

In a study, commissioned by the Federal Ministry of Finance, financial economists produced data inter alia on the scope and structure of the crowdlending market over the period from 2007 to $2015 .{ }^{7}$ The findings show an enormous growth of this largest segment of the crowdfunding market (totaling at

Securities Laws, 2012 Colum. BUS. L. REV. 1, 103-4; for an account in the business press that envisions a far-reaching substitution of banks as providers of credit see Editorial, Banking without banks, THE ECONOMIST, 1 Mar 2014, at 70; for a delineation of crowdinvesting's potential in Europe see Dirk A. Zetzsche \& Christina Preiner, CrossBorder Crowdfunding - Towards a Single Crowdfunding Market for Europe 6-8 (EBI Working Paper No. 8, 2017), https://ssrn.com/abstract=2991610; for Germany for instance Alexander Meschkowski \& Frederike K. Wilhelmi, Investorenschutz im Crowdinvesting, 68 BETRIEBS-BERATER (BB) 1411 (2013); specifically on the idea of a relative decrease in the costs of capital as a result of lower search and agency costs in crowdinvesting relationships, Lars Klöhn \& Lars Hornuf, Crowdinvesting in Deutschland, 24 ZEITSCHRIFT FÜR BANKRECHT UND BANKWIRTSCHAFT (ZBB) 237, 256-8 (2012) (arguing that the 'wisdom of crowds' is imperfect and partly irrelevant with regard to relevant agency relationships.

${ }^{5}$ For an overview of the policy issues see John Armour \& Luca Enriques, The Promise and Perils of Crowdfunding: Between Corporate Finance and Consumer Contracts 12-17 (Eur. Corp. Gov. Inst. Working Paper No. 366/2017), http://ssrn.com/abstract_id=3035247; Zetzsche \& Preiner, supra note 4 at 9-16. The European Securities and Markets Authority (ESMA) has also identified what it considers key components for an adequate regulatory reaction to the new phenomenon and outlined several specific responses that draw-on and develop the existing EU regulatory framework, ESMA, OPINION: INVESTMENT BASED CROWDFUNDING 10-12 and 12-27.

${ }^{6}$ But see Gregor Dorfleitner \& LARS Hornuf, FinTECH MARKT In DeUtSCHLAND 22-5 (2016), http://www.bundesfinanzministerium.de/Content/DE/Standardartikel/Themen/Internationales_Finanzmarkt/2016-11-21-Gutachten-Langfassung.pdf?_blob=publicationFile\&v=1 (presenting aggregate data for the donation based and reward based crowdfunding markets that includes campaigns initiated by Germans on international platforms and showing that the overall funding capacity - EUR 85 million between 2007 and 2015 - is small relative to other crowdfunding markets and dominated by three players, although sourcing occurs through a large number of intermediaries).

7 DORFLEITNER \& HORNUF supra note 6 at 32-5. For older data see Moritz Renner, "Banking Without Banks"? Rechtliche Rahmenbedingungen des Peer-to-Peer Lending, 26 ZBB 261, 262 (2014). 
EUR 400 million of credit extended until the end of 2015 with average annual growth rates of $95 \%^{8}$ ) with a significant slowdown during the economic downturn and even a decline of $22 \%$ in 2011 . While P2P-lending to consumers occurred relatively early in the development, crowdlending to businesses proves to be a rather new phenomenon, albeit with staggering growth rates. ${ }^{9}$ Until the end of the observation period, the market was dominated by one player (Auxmoney), mainly used to roll-over existing loans or overdrafts and exhibited relatively high default rates. ${ }^{10}$ This arguably induced platforms to impose stricter access conditions for users seeking credit (presentation of credit ratings). They thus assumed a more momentous role as gatekeepers. ${ }^{11}$

\subsubsection{Crowdinvesting}

In an interdisciplinary research project, Germany's preeminent scholars in the field produced descriptive statistics on the domestic crowdinvesting market. ${ }^{12}$ The most relevant take away from the data is not that the initial upward trend in the funds raised (a total of almost 53 million Euro since the first crowdinvestment initiative in August 2011) has abated recently, ${ }^{13}$ but that fundraising is largely concentrated at two platforms (Seedmatch and Companisto). These key players also are highly successful in placing the issues of start-ups (the success rate was $100 \%$ and $95 \%$ respectively), whereas other platforms also have a significant fraction of failed offers that do not reach the funding-threshold. With all due reservations concerning methodologically unhedged inferences, the data seems to indicate that platforms perform gate-keeper functions ${ }^{14}$ and are in a position to build reputational capital not only in this respect but also as information intermediaries.

${ }^{8}$ This observation tallies with the global trend see Renner supra note 7 at 263.

${ }^{9}$ See also ZHANG ET AL., SUSTAINING MOMENTUM 54 (2016), https://www.jbs.cam.ac.uk/fileadmin/user_upload/research/centres/alternative-finance/downloads/2016-european-alternative-finance-report-sustainingmomentum.pdf (showing P2P-lending to consumers growing slower than P2P-lending to businesses, although on a higher level between 2013 and 2015). Projections indicate that the trend will continue in the future, see Statista, Alternative Lending Segment Report (2018), https://de.statista.com/outlook/334/137/crowdlending-business-/deutschland\# (reporting annual growth rates of $45.7 \%$ in the P2P business lending market until 2022 ultimately reaching EUR 2,658 million).

${ }^{10}$ See also Gregor Dorfleitner et al., Description-text related soft information in peer-to-peer lending Evidence from two leading European platforms, 64 J. BANKING \& FIN. 169 (2016) (reporting default rates of 12-14\% for Germany's leading lending platforms).

${ }^{11}$ On the procedures of German crowdlending platforms see also Renner supra note 7 at 263.

12 Lars Klöhn, Lars Hornuf \& Tobias Schilling, Crowdinvesting-Verträge, 28 ZBB 142, 143-5 (2016); for similar observations see DORFLEITNER \& HORNUF supra note 6 at 26-31; more recent data for 2016 corroborates the general trend, see STATISTA, GESAMTVOLUMEN DES DURCH CROWDINVESTING EINGESAMMELTEN KAPITALS IN DEUTSCHLAND VON 2011 BIS Q4 2016 (2018), https://de.statista.com/statistik/daten/studie/258158/umfrage/volumen-des-durchcrowdinvesting-eingesammelten-kapitals-in-deutschland/. For additional empirical evidence see also Sascha Herr \& Ulrich Bantaleon, Crowdinvesting als alternative Unternehmensfinanzierung - Gundlagen und Marktdaten in Deutschland, 53 DeUTSCHES StEUERRECHT (DSTR) 532, 535 (2015); for granular data on the early phase, Klöhn \& Hornuf, supra note 4 at 239-46.

${ }^{13}$ See also Christopher Danwerth, Crowdinvesting - Ist das Kleinanlegerschutzgesez das junge Ende einer innovativen Finanzierungsform, 28 ZBB 20, 22 (2016) (observing above average growth of crowdinvesting only in real estate, ecological project and movie financing).

${ }^{14}$ For anecdotal evidence on very high rejection rates of up to $99 \%$, see also Lars Hornuf \& Armin Schwienbacher, The Emergence of Crowdinvesting in Europe: With an In-Depth Analysis of the German Market 25 note 12 (LMU Discussion Paper 2014-43, 2015), https://epub.ub.uni-muenchen.de/21388/1/Hornuf\%20Schwienbacher\%20-\%20The\%20Emergence\%20of\%20Crowdinvesting\%20in\%20Europe.pdf. 


\section{Definition - Legal qualification of crowdfunding}

\subsection{How is crowdfunding defined in your legal order?}

German law does not know any statutory or otherwise authoritative definition of crowdfunding. In line with the General Rapporteur's understanding, an influential scholarly contribution defines crowdfunding as "collecting financial contributions from a multitude of persons to achieve a common goal through the use of a specialized internet platform".${ }^{15}$ Even more broadly, the German Federal Financial Supervisory Authority (Bundesanstalt für Finanzmarktaufsicht, BaFin), understands crowdfunding as "a type of financing which is usually raised over internet platforms" ${ }^{16}$ Although definitions vary in detail, ${ }^{17}$ the common theme recurs that crowdfunding campaigns are conducted over the internet or through social media and that demand and supply are matched online.

\subsection{Does the definition include the following features?}

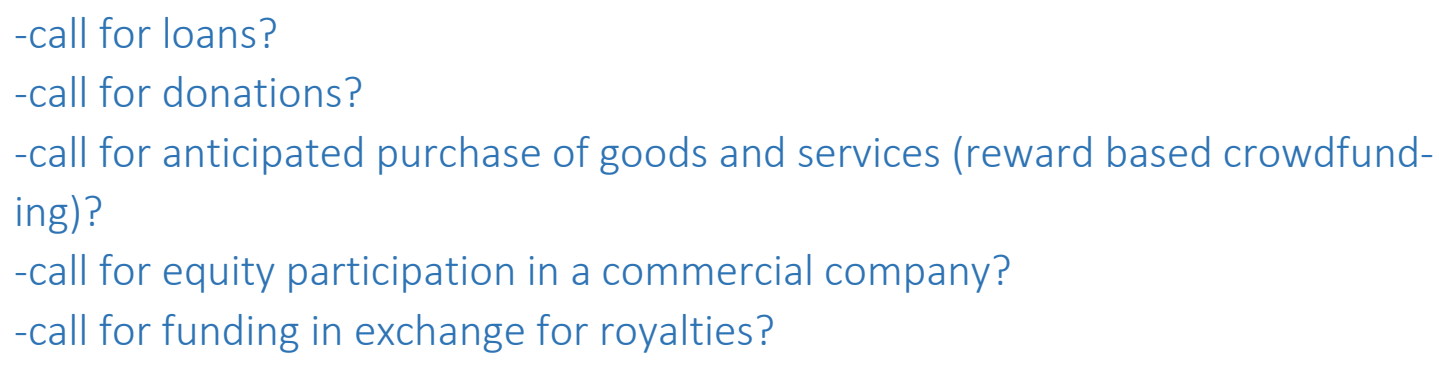

Terminological variations in the German scholarly debate aside, it is useful to distinguish several subcategories of crowdfunding. They are characterized by the diverging objectives that parties pursue with their transactions, which in turn shape the consideration stipulated in the contract. ${ }^{18}$ In Crowdponsoring contributors receive no financial compensation but support a specific project with donations. ${ }^{19}$ Alternatively, contributions are rewarded with a (nominal) non-monetary benefit ("goodies") if the campaign is successful, like for instance an acknowledgement on the cover of music media

${ }^{15}$ Lars Klöhn, Lars Hornuf \& Tobias Schilling, Regulation of Crowdfunding in the German Small Investor Protection Act: Content, Consequences, Critique, Suggestions, 13 Eur. CoMP. L. 56 note 3 (2016); see already Klöhn $\&$ Hornuf, supra note 4 at 239. This understanding tallies with definitions present in the international literature, see for instance Thomas Lee Hazen, Crowdfunding or Fraudfunding - Social Networks and the Securities Laws Why the Specially Tailored Exemption Must Be Conditioned on Meaningful Disclosure, 90 N.C. L. Rev. 1735, 1736 (2012) (defining crowdfunding as sub-category of crowdsourcing "which refers to mass collaboration efforts through large numbers of people, generally using social media or the Internet"); similarly Heminway \& Hoffman, supra note 4 at 881 .

${ }^{16}$ https://www.bafin.de/EN/Aufsicht/FinTech/Crowdfunding/crowdfunding_node_en.html

${ }^{17}$ See for instance Meschkowski \& Wilhelmi, supra note 4 at 1411 (referring to the Wikipedia definition, which also highlights the collective effort in raising resources over the internet to support projects); see also Jean David Jansen \& Theresa Pfeifle, Rechtliche Probleme des Crowdfunding, 33 ZEITSCHRIFT FÜR WIRTSCHAFTSRECHT (ZIP) 1842,1843 (2012) (pointing to the origins of crowdfunding in sponsoring charitable or altruistic projects through web-campaigns).

${ }^{18}$ For a distinction between altruistic and financially motivated crowdfunding see for instance ELFRIEDE SIXT, SCHWARMÖKONOMIE UND CROWDFUNDING 57 (2017). For a prudential supervisor's distinction of loan based crowdfunding on the one hand and investment based crowdfunding on the other see Fin. Conduct Auth., The FCA's regulatory approach to crowdfunding over the internet, and the promotion of non-readily realisable securities by other media 5-6 (Policy Statement 14/4, 2014), https://www.fca.org.uk/your-fca/documents/policystatements/ps14-04.

${ }^{19}$ The prototypical instance can be seen in Barack Obama's fund raising campaign for his initial election, see Tamahan Bradley, Final Fundraising Figure: Obama's \$750M, ABC NEWs, Dec. 5, 2008, http://abcnews.go.com/Politics/Vote2008/story?id=6397572. 
or in the credits at the end of a movie..$^{20}$ Alternatively, the consideration can have material value, for instance if supporters of crowdfunding campaigns receive the product from the first batch of production or at least acquire the preferential right to purchase the product at a reduced price immediately after it was initially manufactured (reward based or pre-selling crowdfunding). ${ }^{21}$ The funding relationship exhibits an even clearer character as an exchange agreement if a financial consideration is stipulated, ${ }^{22}$ either as fixed compensation (interest) for the temporary provision of liquidity ${ }^{23}$ (crowdlending) or as variable, performance-related payment that flows from investments in a business venture in the form of equity or mezzanine-capital instruments (crowdinvesting or commercial crowdfunding). ${ }^{24}$ Finally, a similar arrangement occurs where supporters participate in the exploitation of copyrights, patents and similar intellectual property rights that was facilitated through their crowdfunding contributions, for instance by receiving a share of the royalties paid to an artist. ${ }^{25}$

\subsection{Please specify the legal qualifications used in your legal order for the different kinds of funding aforementioned. In particular, are those different kinds of funding easily assimilated to well-known legal categories of your legal order? For instance, is the reward-based crowdfunding type, when consisting of an anticipated pur- chase of goods and services, qualified as a sales contract of goods or services? Is the legal qualification different if the loan aims at financing a real estate project or a project dealing with moveable assets?}

The general stance of German contract law towards crowdfunding is determined by the fundamental principle of freedom of contract. ${ }^{26}$ This holds true even for crowdinvesting instruments that grant sponsors participation rights in a business venture's future cash flows, because, as a matter of law, the hybrid capital instruments typically offered, constitute debt contracts that are unaffected by corporate law's rigidity. ${ }^{27}$ This latitude enables initiators of crowdfunding campaigns to structure the respective financing relationships to fit their preferences. It should not be neglected though, that the latter are frequently shaped by an appetite to avoid the constraints of banking and securities regulation. However, as initially noted, the legal qualification of financing relationships concluded on platforms poses

20 Jansen \& Pfeifle supra note 17 at 1843; Andreas Bareiß, Filmfinanzierung 2.0, ZEITSCHRIFT FÜR URHEBERUND MedienRECHT (ZUM) 456, 460 (2012). For a delineation of possible designs see also DANA Melanie SCHRAMm \& JAKob CARSTENS, StARTUP-CROWdFUndING UND CROWDINVESTING: EIN GUIDE FÜR GRÜNDER 7 (2014).

${ }^{21}$ SIXT supra note 18 at 113.

${ }^{22}$ For a delineation of the respective categories see Kai Bodensiek \& Caroline Leinemann, Rechtliche Einordnung des Crowdfundings in Deutschland 3-4 (Revue générale du droit, Études et réflexions No. 5, 2015), http://www.revuegeneraledudroit.eu/wp-content/uploads/ER2015_5.pdf; MARKUS FORSTER, CROWDFINANCING 19 (2013); SIXT supra note 18 at 57-8; SCHRAMM \& CARSTENS supra note 20 at 7.

${ }^{23}$ On this fundamental feature of loan contracts see Tobias Tröger, Loan, in THE MAX PLANCK ENCYCLOPEDiA OF EUROPEAN PRIVATE LAW 1106, 1108-9 (Jürgen Basedow, Klaus J. Hopt \& Reinhard Zimmermann, eds., 2012).

${ }^{24}$ Specifically on the definition of crowdinvesting as a form of financing of companies by granting an interest in the firm's future cash-flows, Tobias H. Tröger, Remarks on the German Regulation of Crowdfunding,

12 ReVUe TRIMESTRIELLE DE Droit FINANCIER (RTDF) 79 (2017); similarly Klöhn, Hornuf \& Schilling supra note 15 at 56 note 4 (2016); Klöhn \& Hornuf supra note 4 at 239.

25 Jansen \& Pfeifle supra note 17 at 1843; Bareiß supra note 20 at 461-2.

${ }^{26}$ Bürgerliches Gesetzbuch [BGB] [Civil Code], Aug. 18, 1896, RGBL. at 195, § 311 para. 1, translation at https://www.gesetze-im-internet.de/englisch_bgb/ empowers any person to create an obligation by contract.

${ }^{27}$ The German stock corporation law does not allow any material alteration of the statutory rights and duties of shareholders, Aktiengesetz [AktG] [Stock Corporation Act], Sept. 6, 1965, BGBI. I at 1089, § 23 para. 5. Even for other legal forms of business organizations, German law adheres to the principle of numerus clausus limiting the latitude to customize membership interests, see for instance KARSTEN SCHMIDT, GESELLSCHAFTSRECHT 968 (4th ed., 2002). 
no idiosyncratic challenge for German private law, because, in principle, all funding relationships existed prior to digitization in the analogue world and technological innovation only facilitated their conclusion among previously unacquainted parties.

\subsubsection{Crowdsponsoring}

If contributions to the campaign are made as donations or no-interest "loans" without repaymentobligation the qualification as an immediately executed gift contract ("Handschenkung") within the meaning of $\S 516 \mathrm{BGB}$ is straightforward. ${ }^{28}$ The classification requires that the contribution is indeed made without consideration, which is only the case if the grant does not legally depend on any return, however small. ${ }^{29}$ Quite importantly, promises of non-monetary rewards also qualify as consideration that preclude the qualification as a gift contract. ${ }^{30}$ However, crowdfunding campaigns where initiators promise no more than to publicly announce the name of the contributor do not necessarily provide for such a non-monetary compensation. If the mentioned name is only one among many others of those who made (small) contributions, the typical credits can be qualified as legally irrelevant reference to the gift. ${ }^{31}$ Only if the way the contribution is supposed to be mentioned is more prominent and thus allows for increased (media) attention, the relationship between the initiator and the contributor can be qualified as sponsoring contract, ${ }^{32}$ where the publicity of the contribution materially serves the communicative purposes of the benefactor and promising such publicity thus constitutes a relevant compensation for the granted funds. ${ }^{33}$

Moreover, German private law requires that both parties agree that the contribution occurs without consideration, i.e. that there is a contractual consensus on its gratuitousness. ${ }^{34}$ Such a consensus exists if the contribution is neither in a synallagma with a consideration, nor the condition, nor the cause of law for such a quid pro quo. ${ }^{35}$ Hence, if contributors enter into a legally binding arrangement that promises them a material advantage in the form of an incentive or a goody (for instance a free download of funded music productions or meetings with the artist), the contract cannot be comprehensively qualified as a donation. ${ }^{36}$ However, if the parties are aware of a significant mismatch between the higher value of the contribution and the lower one of the consideration, German doctrine

28 Jansen \& Pfeifle supra note 17 at 1843; Bareiß supra note 20 at 460.

${ }^{29}$ Reichsgericht [RG] [Imperial Court of Justice] Jan. 30, 1940, 125 Entscheidungen des Reichsgerichts in Zivilsachen [RGZ] 380 (383); Bundesgerichtshof [BGH] [Federal Court of Justice] Sept. 23, 1981, 82 Entscheidungen des Bundesgerichtshofs in Zivilsachen [BGHZ] 274 (280-2); Jens Koch, \& 516 BGB para. 24, in MüNCHENER Kommentar ZUM BGB, Vol. III (Franz Jürgen Säcker et al. eds., 7th ed., 2016); Tiziana J. Chiusi, § 516 BGB para. 49, in J. VON StAUdingers KOMMENTAR ZUM BGB MIT EINFÜHRUNGSGESETZ UND NEBENGESETZEN (2013).

${ }^{30}$ BGH Oct. 2, 1991, 45 NEUE JURISTISCHE WOCHENSCHRIFT (NJW) 238, 239 (1992); Koch supra note 29 at § 516 para. 25; Chiusi supra note 29 at $§ 516$ para. 40.

${ }^{31}$ For a similar assessment see Bareiß supra note 20 at 461.

32 Under German private law, sponsoring contracts are construed as a combination of service and work and labor contracts, see ReNATE SCHAUB, SPONSORING UND ANDERE VERTRÄGE ZUR FÖRDERUNG ÜBERINDIVIDUELLER ZWECKE 208-11 (2008).

33 Bareiß supra note 20 at 461.

${ }^{34}$ Koch supra note 29 at $\S 516$ para. 14, 24; Chiusi supra note 29 at $\S 516$ para. 49.

${ }^{35}$ For this majority view see for instance BGH Nov. 27, 1991, 116 BGHZ 167 (170); Koch supra note 29 at $\S 516$ para. 27. For an overview of the development of the doctrine see MICHAEL FISCHER, DIE UNENTGELTLICHKEIT IM ZIVILRECHT 42-4 (2002); for a critique see Jan Dirk Harke, § 516 BGB para. 67-70, in BECK'SCHER ONLINE GROSSKOMMENTAR ZUM BGB (Beate Gsell et al. eds., 2018).

${ }^{36}$ Bareiß supra note 20 at 461; Jansen \& Pfeifle supra note 17 at 1843. 
splits the transaction into two independent contracts ${ }^{37}$ and thus treats the overshooting fraction of the contribution as a donation ${ }^{38}$ and its compensated part as reward based crowdfunding contract. ${ }^{39}$

\subsubsection{Reward based crowdfunding}

If investors in successful crowdfunding campaigns receive access to the product as a consideration for their contribution, for instance a physical delivery from the first manufacturing batch, a data carrier with the produced movie or music album or a download code for it, the underlying contract can easily be qualified as a sale. ${ }^{40}$ If contributors acquire only a right to buy the product (at a reduced price), the contractual relationship is a purchase of rights which is explicitly qualified as a sale in BGB $\S 453$ para. $1 .{ }^{41}$ If media can only be streamed and no download-to-own is possible, the contractual relationship between investors and benefactors of crowdfunding campaigns represents a rental agreement. ${ }^{42} \mathrm{Gen}$ erally, if the product value (market price) or the price of the acquired right is - in accordance with the parties agreement - lower than the contribution, the transaction may be treated as consisting of two separate contracts. ${ }^{43}$

\subsubsection{Crowdlending/P2P lending}

$\mathrm{P} 2 \mathrm{P}$ lending leads to regular, typically unsecured loan agreements. ${ }^{44}$ Loans to finance the acquisition of real estate, in principle subject to the same provisions in the German civil code, are practically nonexistent, because such transactions are typically executed through special purpose vehicles in crowdinvesting (infra 1.3.4).

However, direct contracting between lenders and borrowers, mediated through the platform as an agent, would trigger undesirable regulatory consequences ${ }^{45}$ and is therefore rare in Germany as operators have adjusted their business models. Although platforms match lenders and borrowers, they interpose a credit institution in the transaction that contracts with both the credit seeking and the

${ }^{37}$ If transactions are qualified as "mixed donations", see for instance Jansen \& Pfeifle supra note 17 at 1843 note 6 , these classifications are misguided. Only if the discrepancy in value was indeed reverse, i.e. the consideration was worth more than the consideration, the transaction would be treated as a mixed donation, that is a single contract that combines elements of a donation and a sale (negotium mixtum con donatione), $\mathrm{BGH}$ Sep. 23, 1981, 82 BGHZ 274 (281-2); Koch supra note 29 at $\S 516$ para. 34; Chiusi supra note 29 at $\S 516$ para. 63. However, as a matter of pure economic rationality, it is almost inconceivable that the value of the consideration is higher than the crowdfunding contribution, because then the campaign would lose money and miss its primary purpose.

${ }^{38}$ Koch supra note 29 at $\S 516$ para. 34; Harke supra note 35 at $\S 516$ para. 104-5; Susanne Hähnchen, $\S 516$ para. 28, in ERMAN BÜRGERLICHES GESETZBUCH (Harm Peter Westermann et al., eds., 15th ed., 2017); GEORGIOS Dellios, ZUR PräZIsIerung der ReChTSFIndungsmethode BEI „GEMISCHTEN“ VertRÄGEN 103-4 (1981); for a critique see Wolfgang Ernst, Entgeltlichkeit - Eine Untersuchung am Beispiel des Tauschs, der gemischten Schenkung und anderer Verträge, in FESTSCHRIFT FÜR EDUARD PICKER 139, 170-1 (Thomas Lobinger et al., eds., 2010).

39 On the precise legal qualification of the latter, see infra 7.

${ }^{40}$ Bareiß supra note 20 at 461 . If the campaign pertains to the production of a tangible good, the contract is one for work and materials ("Werklieferungsvertrag"), to which sales law also applies, cf. BGB, §650 s. 1.

${ }^{41}$ For the general qualification of the acquisition of purchase rights for a consideration as a sale of rights see Harm Peter Westermann, § 453 BGB para. 4, in MüNCHENER KOMMENTAR ZUM BGB, Vol. III (Franz Jürgen Säcker et al. eds., 7th ed., 2016).

42 id.

${ }^{43}$ See supra 1.3.1.

44 Renner supra note 7 at 263; see also Sven Christian Berger \& Bernd Skiera, Elektronische Kreditmarktplätze: Funktionsweise, Gestaltung und Erkenntnisstand bei dieser Form des „Peer-to-Peer Lending“, 45 KREDIT UND KAPITAL 289, 291 (2012) (showing that a leading platform foresees that acquired cars are used as collateral in auto loans).

${ }^{45}$ See infra 0. 
funding party. ${ }^{46}$ On the one hand, the borrower takes out a loan from the credit institution, procured by the platform that earns a service fee (borrowing fee). On the other hand, the funding party purchases the redemption claim, which is subsequently assigned once the bank disburses the loan. ${ }^{47}$ As economic result of the transaction, the investor holds a claim against the borrower just like she would, if she had contracted directly with him. ${ }^{48}$ This observation begs the question whether a differential treatment in regulation (see infra 3.1.1) can be justified as a matter of public policy.

\subsubsection{Crowdinvesting}

Contributors to crowdinvesting campaigns receive a variable compensation that hinges on the financed venture's future cash flows. The specific design of the arrangements varies ${ }^{49}$ and the observable differences are relevant for the legal qualification of the contractual relationships, the parties typically enter into. In the vast majority of cases, the project executing organization or person enters into direct contractual relationships with investors through the platform, whereas arrangements in which a special purpose entity bundles investments and then contracts with the initiator are rare. ${ }^{50}$

The main contribution of recent empirical research is that it illuminates the legal structure of typical crowdinvestment products offered through the platforms to finance business ventures. ${ }^{51}$ These insights are of critical importance, because they determine, how and to what extent crowdinvesting indeed affects the policy objectives of financial regulation. The legal structure of the investment products sold on crowdinvesting platforms defines both the cash-flow and governance rights vested with investors which in turn are crucial at least for investor protection, but also impact on financial stability concerns.

Issuers typically structure the financing relationship as unsecuritized term-debt ${ }^{52}$ with fixed interest rates ${ }^{53}$ and various extents of profit participation. ${ }^{54}$ Moreover, in most cases investors also participate in an increase of the going-concern value of the issuer. ${ }^{55}$ Loss participation is limited to the funds invested in gone concern scenarios. ${ }^{56}$ Contractual arrangements in the indenture subordinate

${ }^{46}$ Renner supra note 7 at 264.

${ }^{47}$ Sometimes, in order to minimize the need for costly information sharing, the credit-extending bank sells and assigns the redemption claim to a servicing firm, which is linked to the platform and subsequently passes the claim on to the ultimate investor, Renner supra note 7 at 264.

${ }^{48}$ In the U.S., the same result is reached with synthetic notes that replicate the cash flows from the loans platforms themselves extend and that are acquired by investors who may also trade on a secondary market, see Jonnelle Marte, Credit Crunch gives 'Microlending' a Boost, WALL ST. J. Sep. 26, 2010 at 1.

${ }^{49}$ For anecdotal evidence in addition to the empirical findings reported infra see Jansen \& Pfeifle supra note 17 at 1844; Bareiß supra note 20 at 461.

${ }^{50} \mathrm{Klöhn,} \mathrm{Hornuf} \mathrm{and} \mathrm{Schilling,} \mathrm{supra} \mathrm{note} 12$ at 145.

${ }^{51}$ The following section reiterates the main findings in Klöhn, Hornuf and Schilling, supra note 12 at 148 178.

52 Id. at 149 and 152-4 (showing that contracts usually are loan agreements that can be terminated after 5-7 years after a minimum notice period has elapsed and automatic termination after a fixed contract term representing an exception).

${ }^{53} \mathrm{Id}$. at $155-6$ (finding annual interest rates varying from $1 \%$ to $8 \%$ and due either upon redemption, or periodically (annually, quarter-annually)).

${ }^{54} \mathrm{Id}$. at $158-60$ (identifying an unlimited pro-rata profit participation in four fifth of the cases and a capped participation in others)

${ }^{55} \mathrm{Id}$. at 161-5 (describing that investors either receive a payment based on an appraisal of the issuer at the time the investment is terminated or a fraction of the proceeds that accrue to equityholders if they sell their shares)

${ }^{56} / d$. at 160 (also showing that liability was sometimes not limited in the past). 
the redemption claim to all other claims against the issuer. ${ }^{57}$ The contractual relations that underlie typical German crowdinvestments seek to mimic equity-like risk and return-structures. This becomes even more apparent, if the protection against claim dilution in the case of follow-up funding is considered, ${ }^{58}$ which prevents new investors from externalizing risk to old ones and benefiting disproportionately from future cash-flows.

However, the governance rights granted to investors on crowdinvesting platforms are a far cry from those vested with shareholders. In essence, investors do not have any influence on the decisionmaking process at the issuer concerning questions of management and business strategy. ${ }^{59}$ However, contracts provide for periodic disclosure of key financial and other relevant data that in some cases initiators also have to explain at web-based annual investor meetings. ${ }^{60}$ Control rights beyond the entitlement to candid disclosure are almost non-existent. ${ }^{61}$

Essentially, German law provides three types of contractual arrangements that conform to the rights and obligations the parties seek to establish in crowdinvesting transactions. ${ }^{62}$ The relationship between contributors and initiators of crowdinvesting campaigns can be framed as either silent partnerships, ${ }^{63}$ profit participation rights ("Genussrechte"), ${ }^{64}$ or subordinated profit-participating loans ("partiarische Nachrangdarlehen"). ${ }^{65}$ The precise classification of individual agreements is difficult and courts explicitly follow a case by case approach ${ }^{66}$ However, key indicators are the lack of monitoring and control rights, which militates against a qualification as (silent) partnership, ${ }^{67}$ the existence of a fixed repayment claim combined with a participation in the ventures profits or turnover, which speaks

${ }^{57} \mathrm{Id}$. at 177-8. The reason for the subordination comes from prudential banking regulation which would submit borrowers to an authorization requirement, if the loans were not subject to a specific subordination clause, see Dörte Pölzig, Nachrangdarlehen als Kapitalanlage, 68 WERTPAPIER-MITTEILUNGEN (WM) 917, 919 (2014).

${ }^{58} \mathrm{Id}$. at 166-8 (indicating that contracts provide for a proportional adjustment of the participation ratio under which losses can only occur if the issuer is undervalued in the new round of financing).

59 Id. at 168.

${ }^{60} / d$. At 168-73 (describing that disclosure obligations provide inter alia for quarterly reporting, disclosure of annual accounts, overview of profit- and revenue participation).

61 Id. at 173-76; Jansen \& Pfeifle supra note 17 at 1844.

${ }^{62}$ For instance Jansen \& Pfeifle supra note 17 at 1846; Bareiß supra note 20 at 461; Klöhn, Hornuf and Schilling, supra note 12 at 145; on the development of the market, which clearly shifted towards subordinated profit participating loans in reaction to prudential regulation see Klöhn, Hornuf \& Schilling supra note 15 at 58 9.

63 See generally Handelsgesetzbuch [HGB] [Commercial Code], May 10, 1897, RGBL. 219, §§ 230-6 HGB, translation at https://www.gesetze-im-internet.de/englisch_hgb/englisch_hgb.pdf.

64 The latter have not received a special treatment neither in the German Civil nor the Commercial Code, but are anticipated in different legislative acts, like for instance Capital Investment Act [Vermögensanlagengesetz, VermAnIG], Dec. 6, 2011, BGBL. I at 2481, § 1 para. 2 Nr. 4, https://www.gesetze-im-internet.de/vermanlg/ or AktG, $\S 221$ paras. 3 and 4 . The lack of statutory prescriptions together with the fundamental principle of freedom of contract allow for a highly flexible individual design of parties' obligations in these profit participation rights.

65 The contract combines a regular loan with an additional stipulation of sharing in the profits or sales that flow from the investment of the borrowed funds as compensation for the lender, see for instance Karsten Schmidt, § 230 HGB para. 54, in MünCHENER KommentAR ZUM HGB, Vol. 3 (Karsten Schmidt, ed., 3rd ed. 2012); Carsten Schäfer, Vor $\S 705$ BGB para. 107, in MünCHENER KOMMENTAR ZUM BGB, Vol. 6 (Franz Jürgen Säcker et al. eds., 7th ed., 2017); HeNNING HUfFER, DAS PARTIARISCHE GESCHÄFt ALS RECHTSTYPUS (1970).

${ }^{66}$ RG May 11, 1920, 99 RGZ 161 (163), BGH Jun. 6, 1965, 19 WM 1965, 1052 (1053); Robert Freitag, $\S$ 488 BGB para. 70, in J. von StAUdINGERs KOMMENTAR ZUM BGB MIT EINFÜHRUNGSGESETZ UND NEBENGESETZEN (2015); UWE BLAUROCK, HANDBUCH DER STILLEN GeSELLSCHAFT para 8.30 (7th ed. 2010).

${ }^{67}$ See HGB $\S 233$ para. 1, which describes typical control rights of a silent partner. 
in favor of a profit participating loan contract, ${ }^{68}$ whereas the absence of such a repayment claim and a loss participation not only in gone-concern scenarios hints at the classification of the financing relationship as a profit participation right or a silent partnership. ${ }^{69}$ To distinguish the latter alternatives, it is important whether the crowdfunding relationship obliges contributors to further the project (common purpose) beyond their financial contribution. ${ }^{70}$

At times, commentators sought to establish a separate category for single project financing relationships like movie productions or music albums. ${ }^{71}$ However, this further distinction does not seem necessary, as these contracts can be understood as loans with (subordinated) fixed repayment obligations, ${ }^{72}$ making the value of the latter hinge on the performance of a single asset and thereby leading to an automatic loss-participation of investors up to the contributed amount. Alternatively the respective financing relationships can also be construed as profit participation rights granted by the producing entity, where no repayment claim exists and a loss participation is possible. ${ }^{73}$

\subsection{Has the legislator dealt with those questions? Is the chosen legal qualification ap- proved by the legal doctrine? By yourself?}

There has been no legislative intervention with regard to the private law qualification of contracts concluded on crowdfunding platforms. This is understandable, given that the existing German private law framework allows parties to structure their financing relationships according to their economic goals. The financing objectives can be achieved with sufficient legal certainty. Parties can draw on wellestablished and thus broadly approved doctrinal concepts, which are applied to crowdfunding activities. ${ }^{74}$ Deviations from the majority view in the literature are confined to narrow aspects, remain an exemption and are ultimately not convincing. ${ }^{75}$

\subsection{What kind of financial contributions are possible? May the contribution consist of something other than cash?}

As a matter of law, there are no crowdfunding specific restrictions with regard to the form financial contributions can take. The financing relationship imposes a monetary debt on contributors to which the general rules in the law of obligations apply. As a default, these rules limit admissible methods of performance to cash, but afford parties the opportunity to consent (tacitly) to the use of contemporary

68 See generally Mathias Habersack, $\S 221$ AktG para. 93, in MünCHENER KommentAR ZUM AkTG, Vol. 4 (Wulf Goette \& Mathias Habersack, eds., 4th ed. 2016); Hanno Merkt, § 221 AktG para. 46, in AktG, Vol. 2 (Karsten Schmidt \& Marcus Lutter eds., 3d ed. 2016).

69 Jansen \& Pfeifle supra note 17 at 1846; Bareiß supra note 20 at 461.

70 See generally Karsten Schmidt, $\$ 230$ HGB para. 54, in MünCHENER KOMMENTAR ZUM HGB, Vol. 3 (Karsten Schmidt, ed., 3rd ed. 2012); Carsten Schäfer, Vor § 705 BGB para. 107, in MünCHENER KOMMENTAR ZUM BGB, VoL. 6 (Franz Jürgen Säcker et al. eds., 7th ed., 2017); in the context of crowdinvesting Jansen \& Pfeifle supra note 17 at 1846; Bareiß supra note 20 at 461.

${ }^{71}$ See Jansen \& Pfeifle supra note 17 at 1846 (submitting that these transactions should be seen as profit participation contracts sui generis).

${ }^{72} \mathrm{Cf}$. BGB $\S 488$ para. 1 sentence 2 declaring a repayment obligation essential part of a loan contract under German law, see also Freitag supra note 66 at $\S 488$ para. 70 . Where investors receive a fraction of each individual sale (for instance a share of each cinema ticket sold), this contract design can be qualified as a special annuity arrangement (until the contribution is repaid) and a profit participation (after repayment).

73 Bareiß supra note 20 at 462 . Given the legal character of the participation rights as debt contracts, such a classification is not excluded simply because investors do not receive an ownership stake in the funded entity (for this view see Jansen \& Pfeifle supra note 17 at 1844-5).

${ }^{74}$ On the lack of legal innovation in pertinent respect see already supra 0.1 .

${ }^{75}$ See supra 1.3.4. 
payment methods and systems like wire transfers, direct debits, credit and debit cards etc. ${ }^{76}$ This means inter alia that bitcoins and other cryptocurrencies are not automatically cash-equivalent means of payment, but parties can consensually declare them suitable means of performance. ${ }^{77}$

\section{Normative Framework}

2.1 Does a law specific to crowdfunding exist? If a specific law does not exist, what are the laws applicable to the activity of crowdfunding? If such specific rules exist, could you please attach to your answers of this questionnaire the text (if an English or French version exists)?

There is no specific law that regulates crowdfunding. Only very limited legislative interventions exist that relax primary market disclosure obligations in securities laws for crowdfunding activities. ${ }^{78}$

2.2 If a specific body of rules exists, does it apply to any type of crowdfunding (donation, loan, purchase of goods and services, equity)? Or is such a body of rules specific to one kind of crowdfunding individually? Is it specific to the purpose of the funding? Is it specific to the aim of the contributors (saving, investment, consumption)?

$\mathrm{n} / \mathrm{a}$

2.3 If a law specific to crowdfunding exists, what is its territorial scope of application? What are the situations targeted by this law? Does the law specifically deal with the location of the project directors/ the platform/ the contributors on the territory?

$\mathrm{n} / \mathrm{a}$

2.4 Are the contracts concluded by means of the platform automatically governed by the law applicable to the crowdfunding activity? Is a choice of law possible?

Typical financing relationships concluded on platforms (see supra 1.3) fall within the remit of the Rome I Regulation. ${ }^{79}$ This is also true for the most common crowdinvesting contracts, the subordinated profit participating loans, which are not negotiable instruments within the meaning of art. 1 para. 1 lit. d) Rome I Regulation. ${ }^{80}$ The same holds true not only for unsecuritized profit participation rights, but also - according to the majority view in the literature - for silent partnership interests. ${ }^{81}$ Although company

${ }^{76}$ For the doctrinal details see for instance Karl-Heinz Fezer, $\S 362$ BGB paras. 16-25a, in MüNCHENER KOMMENTAR ZUM BGB, Vol. 2 (Franz Jürgen Säcker et al. eds., 7th ed., 2016).

77 For a general discussion of the relevant doctrine see Benjamin Beck, Bitcoins als Geld im Rechtssinn, 68 NJW 580, 585 (2015).

${ }^{78}$ See infra 4.1.2.2.

${ }^{79}$ Regulation (EC) No 593/2008 of the European Parliament and of the Council of 17 June 2008 on the law applicable to contractual obligations (Rome I), 2008 O.J. (L 177) 6 [hereinafter Rome I Regulation].

${ }^{80}$ According to the German majority view this requires securitization of the claim to facilitate its transfer by an assignment of the instrument, see for instance Dieter Martiny, Art. 1 Rom I VO para. 58-9, in MüNCHENER KOMMENTAR ZUM BGB, Vol. 12 (Franz Jürgen Säcker et al. eds., 7th ed. 2012); Eva Maria Kieninger, VO (EG) 593/2008 Art. 1 para 15, in INTERNATIONALES VerTRAGSRECHT (Franco Ferrari et al. eds., 3d ed. 2018).

81 Martiny supra note 80 at Art. 1 Rom I VO paras. 65, 72; Kieninger supra note 80 at VO (EG) 593/2008 Art. 1 para 15; Frauke Wedemann, § 230 para. 119, in: HGB (Hartmut Oetker ed., 5th ed., 2017); Wulf-Henning 
law relationships are generally exempt from the regulation's scope of application, ${ }^{82}$ silent partnerships, by their very nature, do not entail an organization but establish only contractual ties between the partners.

For all prevalent forms of crowdfunding, a choice of law is thus possible in principle. ${ }^{83}$ There is no publicly available empirical evidence on whether the option is broadly used in practice. ${ }^{84}$ In any case, the European conflict of laws rules limit the possibility to choose the applicable law in consumer contracts insofar as the consumer would be deprived of the protection afforded to him by provisions that cannot be derogated from by agreement by virtue of the law of the country of his habitual residence. ${ }^{85}$ This rule applies in crowdfunding relationships concluded through German platforms, because even in crowdinvestment the relevant contracts do not establish rights and obligations that constitute a financial instrument within the meaning of the exception from the binding consumer protection afforded under the Rome I Regulation. ${ }^{86}$ However, where platforms seek to derogate German law, the most important consumer protecting rules to be considered in the required comparison with the chosen legal system are the subscription limits stipulated in securities laws. ${ }^{87}$

Where choice of law clauses are not introduced in the respective contracts and consumer protection rules do not apply, ${ }^{88}$ the relationship is governed by the law of the country where the party required to effect the characteristic performance has his habitual residence. ${ }^{89}$ In crowdfunding relationships this points to the law of the country where the contributor lives. ${ }^{90}$

\section{Supervision of crowdfunding activity}

3.1 Do the platforms have to obtain an authorisation or a licence delivered by an authority prior to the exercise of their activity? If yes, what are the conditions to obtain such an authorisation/ licence? Under what conditions can such an authorisation/licence be removed? What is the competent authority to deliver such authorisation/ licence?

Germany has no specific prudential regulation for crowdfunding. Authorization requirements can therefore only flow from the general bodies of law that regulate the financial sector, in particular the

Roth, Internationalprivatrechtliche Aspekte der Personengesellschaften, 43 ZEITSCHRIFT FÜR UNTERNEHMENS- UND GESELLSCHAFTSRECHT (ZGR) 168, 179 (2014); Gerald Spindler, Crowdfunding und Crowdinvesting - Sach- und kollisionsrechtliche Einordnung sowie Überlagerung durch die E-Commerce-Richtlinie, 29 ZBB 129, 139 (2017).

${ }^{82}$ Rome I Regulation, art. 1 para. 2 lit. f).

${ }^{83}$ Rome I Regulation, art. 3 para. 1. On the preconditions for valid clauses in standard terms see Verein für Konsumenteninformation v. Amazon, Case C-191/15, [2016] E.C.R. I___ (delivered Jul. 28, 2016).

84 The anecdotal evidence reported in Spindler supra note 81 at 139 note 144 is inconclusive as the terms and conditions the author cites are those for the relationship between investors and platforms only.

${ }^{85}$ Rome I Regulation, art. 6 para. 2 s. 2.

${ }^{86}$ According to recital 30 of the Rome I Regulation, its art. 6 para. 4 lit. d) pertains only to financial instruments within the meaning of Directive 2014/65/EU of the European Parliament and of the Council of 15 May 2014 on markets in financial instruments and amending Directive 2002/92/EC and Directive 2011/61/EU, art. 4 para. 17 and Annex I C, [2014] O.J. (L 173) at 349 which does neither capture silent partnership interests, nor profit participation rights, nor subordinated profit participating loans, for a discussion see Spindler supra note 81 at 139.

${ }^{87}$ Infra 4.1.2.2. See also Spindler supra note 81 at 141 (showing that the relevant rules cannot be qualified as overriding mandatory provisions within the meaning of Rome I Regulation, art. 9 para. 1).

${ }^{88}$ Rome I Regulation, art. 6 para. 1 points to the law of the country of the consumer's habitual residence.

${ }^{89}$ Rome I Regulation, art. 3 para. 1.

${ }^{90}$ For a specific discussion, albeit focused on crowdinvesting relationships see Spindler supra note 81 at 140. 
regulations governing credit institutions and investment services firms. The intermediation of donation and reward based crowdfunding does not constitute an activity that can come under the regimes of prudential banking and capital market regulation, as long as platforms avoid collecting the funds from contributors beforehand. ${ }^{91}$ However, the case of crowdlending (infra 3.1.1) and crowdinvesting (infra 3.1.2) is less straight forward and largely depends on platforms' business model. Where the latter leads to licensing requirements, the applicable regime for obtaining and withdrawing licenses is that prescribed for credit institutions and investment firms respectively (infra 3.1.3).

\subsubsection{Crowdlending/P2P lending}

Whether crowdlending platforms require an authorization under the Banking Act hinges on the qualification of their activity as either banking business or financial service. ${ }^{92}$

At the outset, there is a broad consensus that the primary economic function of platforms, to broker credit, does not constitute banking business within the meaning of the law, ${ }^{93}$ particularly because simple loans do not represent financial instruments and hence the activity of platforms does not amount to investment brokerage ("Anlagevermittlung"). ${ }^{94}$ Yet, in the discharge of this function, specific intermediate steps may amount to banking business and thus trigger the authorization requirement.

If platforms collected the monetary contributions from the crowdlenders before forwarding them to borrowers, they might fulfil the statutory elements of "deposit business" ("Einlagengeschäft"). ${ }^{95}$ Although even registered users of the platform would provide "public funds" as required by the law, ${ }^{96}$ platforms can avoid coming under prudential banking regulation by not offering lenders accounts, and collecting the funds in successful campaigns only after the threshold level has been reached and forwarding them as quickly as technically possible to borrowers. This already avoids that the funds will be regarded as "taken" by the platform. ${ }^{97}$ Better still, platforms are even safer, if they have contributions collected and forwarded by a cooperating bank, thereby avoiding acceptance of lenders' funds in the first place.

The challenges platforms face when they wish to avoid that their activities amount to "credit business" ("Kreditgeschäft") ${ }^{98}$ are far more daunting. To be sure, as long as platforms do not issue credits themselves, they do not violate a pre-authorization requirement with their own conduct. ${ }^{99}$ However, they may be held liable for aiding and abetting others in such an infringement of the banking

${ }^{91}$ Otherwise this intermediate step in the discharge of the platform's role can be seen as "deposit business" which requires a banking license, cf. infra 3.1.1.

92 See Banking Act [Kreditwesengesetz, KWG], Sep. 9, 1998, BGBL. I at 2446, § 32, with the relevant definitions codified in KWG, § 1 para. 1a sentence 2 and Securities Trading Act [Wertpapierhandelsgesetz, WpHG], Sep. 9, 1998, BGBL. I at 2708, § 2 para. 3, https://www.gesetze-im-internet.de/wphg/.

93 BaFin, Merkblatt zUR ERLAUbNispflicht der Betreiber und Nutzer einer internetbasierten KreditVerMITTLUNGSPLATTFORM NACH DEM KWG (2007), https://www.bafin.de/SharedDocs/Veroeffentlichungen/DE/Merkblatt/mb_091211_tatbestand_platzierungsgeschaeft.html; Renner supra note 7 at 264.

${ }_{94}$ As defined in KWG $\S 1$ para. 1a sentence 2 no. 1 ; for an extensive discussion of the latter aspect see Julian Veith, Crowdlending - Anforderungen an die rechtskonforme Umsetzung der darlehensweisen Schwarmfinanzierung, 16 ZEITSCHRIFT FÜR BANK- UND KAPITALMARKTRECHT (BKR) 184, 186-7 (2016).

${ }^{95}$ Defined in KWG, $\S 1$ para. 2 No. 1.

${ }^{96}$ Frank A. Schäfer, § 1 KWG para. 46, in KWG, CRR-VO (Karl-Heinz Boos, Reinfried Fischer \& Hermann Schulte-Mattler eds., 5th ed. 2016)

${ }^{97}$ Renner supra note 7 at 265. For a general discussion of the respective element in KWG, § 1 para. 2 No. 1 see Sascha Demgensky \& Andreas Erm, Der Begriff der Einlage nach der 6. KWG-Novelle, 55 WM 1445, 1448 (2001).

${ }^{98}$ As defined in KWG, $\S 1$ para. 2 No. 2.

${ }^{99}$ For the U.S. model which sees platforms extend loans see supra note 48. 
monopoly and supervisors may therefore enjoin their operations. ${ }^{100}$ Under the very extensive interpretation of the elements of "credit business", contributors themselves may in fact be seen as conducting unauthorized banking operations. Any person that extends money loans engages in "credit business" if the activity is commercial. ${ }^{101}$ According to the majority view endorsed by supervisory practice, an activity is commercial if it is intended for a certain period and motivated by an intent to achieve profits. ${ }^{102} \mathrm{~A}$ single transaction may suffice, if there is an intention to extend more loans in the future. ${ }^{103}$ The result of this very restrictive stance is that many investors on crowdlending platforms require indeed a banking license for their activity. ${ }^{104}$

Platforms react to the extensive interpretation of the authorization requirement by favoring the indirect contracting model (supra 1.3.3). ${ }^{105}$ Although it leads to economically identical outcomes, the supervisory practice and the majority view in the literature accept that combining the transactions does not amount to "credit business" for any other party involved then the loan-originating bank and can therefore be conducted without (additional) banking licenses. ${ }^{106}$ In particular, the various activities of platforms in the indirect contracting models also do not constitute banking business. ${ }^{107}$

\subsubsection{Crowdinvesting}

Also with regard to crowdinvesting, licensing requirements for platforms ${ }^{108}$ under the Banking Act hinge on the qualification of their activity as either banking business or investment service. ${ }^{109}$

Regardless of the specific activities that are included in the statutory definitions, any financial and investment service has to pertain to "financial instruments" as defined in banking and securities regulation. ${ }^{110}$ Prior to June 1,2012 , silent partnership interests and unsecuritized participation rights were not included in this definition, essentially liberating crowdinvesting platforms from any authorization requirement and the prudential supervision attached to it. Since June 1, 2012, the definition of

100 KWG, § 37 para. 1 s. 4 empowers BaFin to stop the operations of and wind-down firms that were involved in the initiation, conclusion or execution of prohibited (unauthorized) activities.

${ }^{101} \mathrm{Cf}$. KWG, $\S 32$ para. $1 \mathrm{~s}$. 1. As a matter of practice, the second alternative of the provision, that the activity requires a commercial business organization ("in kaufmännischer Weise eingerichteter Geschäftsbetrieb") is mute, because the elements of a commercial activity are usually met, even though no specific organizational arrangements are necessary.

102 BGH Jul. 11, 2006, 60 Der Betrieb (DB) 2061, 2062 (2006); BAFIN, MerkBLATt Kreditgeschäft (2016), https://www.bafin.de/SharedDocs/Veroeffentlichungen/DE/Merkblatt/mb_090108_tatbestand_kreditges-

chaeft.html; Schäfer supra note 96 at $§ 1$ KWG para. 22.

103 BAFIN supra note 102.

${ }^{104}$ Veith supra note 94 at 186; Renner supra note 7 at 266 (with a critique that favors a more restrictive interpretation); see also Andreas Schwennicke, Vergabe privater Darlehen und Erlaubnispflicht nach dem KWG, WM 542, 548 (2010) arguing in favor of firm de minimis limits.

${ }^{105}$ For an alternative proposal that would retain a direct contracting model but use subordinated loans see Veith supra note 94 at 187.

106 BAFIN supra note 102; Schäfer supra note 96 at $\S 1$ KWG para. 43; Philipp E. Heer, Die Übertragung

von Darlehensforderungen - $\quad$ eine Übersicht

- zugleich Anmerkung zum Urteil des BGH vom 19. 4. 2011 - XI ZR 256/10, 12 BKR 45, 47 (2012).

107 For an extensive discussion see Veith supra note 94 at 188-9.

108 For an overview on the question if issuers need an authorization because they engage in "deposit business" ("Einlagengeschäft") within the meaning of KWG, § 1 para. 2 No. 1, see for instance Michael Nietsch \& Nicolas Eberle, Bankaufsichts- und prospektrechtliche Fragen typischer Crowdfunding-Modelle, 67 DER BETRIEB (DB) 1788,1790 (2014)

${ }^{109}$ Supra 3.1.1.

${ }^{110}$ WpHG § 2 para. 2b; KWG $\S 1$ para. 11 
financial instruments also encompasses "financial assets" within the meaning of the Capital Investment Act, ${ }^{111}$ and since July 10, 2015 these in turn also comprise subordinated profit participating loans. ${ }^{112}$ Hence, the regulatory framework now capture in principle also the typical OTC investment products offered through platforms like for instance silent partnership interests, participation rights or subordinated profit sharing loans.

Therefore, the query has become whether the activity of crowdinvesting platforms with regard to financial instruments constitutes one of the enumerated business activities that are qualified as banking or investment service. The consensus view is that platforms do not engage in underwriting business ("Emissionsgeschäft"), ${ }^{113}$ because they do not assume the risk of a successful placement of the financial instruments issued. ${ }^{114}$ Similarly, the typical platform activities do not constitute placement business ("Platzierungsgeschäft"), ${ }^{115}$ because this would require that the platform acts as agent of the issuer and-according to the interpretation of BaFin - discloses this agency relationship. ${ }^{116}$ Instead, platforms typically only deliver offers to buy or sell as messengers. ${ }^{117}$ However, despite some quibble about the precise meaning of the law, ${ }^{118}$ platforms may indeed engage in investment brokerage ("Anlagevermittlung"), ${ }^{119}$ because they intermediate the acquisition and sale of financial instruments. ${ }^{120}$ According to the majority view, it does not matter whether the transactions occur on the primary or secondary market. ${ }^{121}$ Hence, the execution of initial offerings through crowdinvesting platforms may fall under the definition of investment brokerage and thus constitute banking or investment services that in principle require the platforms' authorization. Be that as it may, brokerage activities that pertain to financial assets are exempt from authorization requirements if brokers acquire property rights neither in the assets nor in the invested funds of the customers. ${ }^{122}$ This precondition tallies perfectly with the typical business model of crowdinvesting platforms. As a consequence, only a special form of trade supervision ("qualifizierte Gewerbeaufsicht") applies. ${ }^{123}$

${ }^{111}$ Capital Investment Act [Vermögensanlagengesetz, VermAnIG], Dec. 6, 2011, BGBL. I at 2481, § 1 para. 2, https://www.gesetze-im-internet.de/vermanlg/.

112 Prior to the 2015 reforms a debate existed about whether the definition of financial assets also included profit participating loans (see for instance Wolfgang Weitnauer \& Josef Parzinger, Das Crowdinvesting als neue Form der Unternehmensfinanzierung, 4 GESELLSCHAFTS- UND WIRTSCHAFTSRECHT (GWR) 153, 155 (2013) (advocating an inclusive definition on normative grounds); Nietsch \& Eberle, supra note 108 at 1790 and 1793 (2014) (opposing such a wide definition).

${ }^{113}$ As defined in KWG, § 1 para. 1 sentence 2 no. 10; WpHG, § 2 para. 3 sentence 1 no. 5.

${ }^{114}$ On the general precondition of a firm underwriting to fall under the statutory regime see Schäfer supra note 96 at $\S 1$ KWG para. 112; Christoph Kumpan, $\S 2$ WpHG para. 72, in KAPITALMARKTRECHTSKOMMENTAR (Eberhard Schwark \& Daniel Zimmer eds., 4th ed. 2010).

${ }^{115}$ As defined in KWG § 1 para. 1a sentence 2 no. 1c; WpHG, § 2 para. 3 sentence 1 no. 6.

116 BaFin, Merkblatt - HinWeise ZUM TAtBestand des Platzierungsgeschäfts (2009), https://www.bafin.de/SharedDocs/Veroeffentlichungen/DE/Merkblatt/mb_091211_tatbestand_platzierungsgeschaeft.html (requiring a disclosed open agency relationship).

${ }^{117}$ Klöhn \& Hornuf, supra note 4 at 249-50.

118 For a detailed description of the relevant provisions' content see Jansen \& Pfeifle supra note 17 at 1850-1; Klöhn \& Hornuf, supra note 4 at 250-1.

${ }^{119}$ As defined in KWG $\S 1$ para. 1a sentence 2 no. 1 ; WpHG, § 2 para. 3 sentence 1 no. 4.

120 See for instance Michael Nietsch \& Nicolas Eberle, Crowdinvesting - Welche Auswirkungen hat das geplante Kleinanlegerschutzgesetz?, 67 DB 2575, 2576 (2014).

121 BaFin, Merkblatt - HinWeise ZUm TAtBestand der AnlageVermittlung (2011); Heinz-Dieter Assmann, § 2 WpHG para. 81, in WPHG (Heinz-Dieter Assmann \& Uwe H. Schneider eds., 6th ed, 2012).

${ }^{122}$ As defined in KWG, $\S 1$ para. 6 no. 8 Buchst. e); WpHG, § 2a para. 1 no. 7 Buchst. e).

123 Trade Regulation [Gewerbeordnung, GewO], Feb. 22, 1999, BGBL. I at 202, § 34 para. 1 sentence 1, https://www.gesetze-im-internet.de/gewo/index.htmI\#BJNR002450869BJNE025705118. 
Finally, authorization requirements could attach to platform activities because they may amount to the operation of a multilateral trading facility (MTF). ${ }^{124}$ It is not convincing when some commentators simply rule-out this possibility by pointing to the regulatory rationale of the underlying European legislative initiatives that sought to capture MTFs as contemporary competitors of exchanges, which - according to this view - requires that platforms also host secondary market trading. ${ }^{125}$ The relevant policy goal of the pertinent regulation is to counter the efficiency losses that are associated with a fragmentation of trade at many venues and in this regard price discovery on primary markets is just as important as that on secondary markets. ${ }^{126}$ In fact, the German supervisor has repeatedly published the interpretation that crowdinvesting platforms can fall under the definition of MTF. ${ }^{127}$ However, it is unclear under which preconditions BaFin will actually find the specific requirement of a "large number" of market participants trading at an MTF met in crowdinvestment initiatives. ${ }^{128}$

\subsubsection{Licensing regime}

If German crowdfunding platforms chose business models that require an authorization as credit institution or investment firm, they would have to fulfil all the requirements put forward in prudential banking or securities regulation, in particular the own funds requirements applicable to banks ${ }^{129}$ and the extensive standards for the conduct and the organization put forward for financial services firms. ${ }^{130}$ Licenses would be revoked, once the platform failed to comply with these requirements. The competence would lie with either the European Central Bank (banking license) ${ }^{131}$ or BaFin (financial services firms).

\subsection{Are the platforms - as intermediaries - subject to the financial intermediaries' law existing in your legal order?}

The application of the relevant regulations hinges on precisely the definitions critical for the determination of licensing requirements. Platforms are therefore typically not subject to the respective rules, like for instance organizational requirements stipulated in the WpHG for investment firms etc. ${ }^{132}$

\subsection{Is the activity of crowdfunding perceived as a banking operation? Does it go against a banking monopoly principle?}

As outlined, platforms can avoid infringing the banking monopoly by structuring their business model accordingly (supra 3.1). In crowdlending this requires resorting to indirect contracting solutions which avoid that credit-extending contributors conduct unauthorized credit operations (supra 3.1.1).

${ }^{124}$ As defined in KWG, § 1 para. 1a no. 1b; WpHG, § 2 para. 3 no. 8. See also Directive 2004/39/EC of the European Parliament and of the Council of 21 April 2004 on markets in financial instruments amending Council Directives 85/611/EEC and 93/6/EEC and Directive 2000/12/EC of the European Parliament and of the Council and repealing Council Directive 93/22/EEC, 4 para. 1 no. 15, 2004 O.J. (L 145) 1 [hereinafter MiFiD].

${ }^{125}$ Klöhn \& Hornuf, supra note 4 at 251.

126 See MiFiD, recital 5.

127 BAFIN, supra note 121; BAFIN, CrowDINVESTING, https://www.bafin.de/EN/Aufsicht/FinTech/Crowdfunding/Crowdinvesting/crowdinvesting_node_en.html.

${ }^{128}$ For a general overview see Assmann, supra note 121 at para. 110.

${ }^{129}$ Regulation (EU) No 575/2013 of the European Parliament and of the Council of 26 June 2013 on prudential requirements for credit institutions and investment firms and amending Regulation (EU) No 648/2012, [2013] O.J. (L 176) 1.

$130 \mathrm{WpHG}, \S \S 63-98$.

${ }^{131}$ Council Regulation (EU) No 1024/2013 of 15 October 2013 conferring specific tasks on the European Central Bank concerning policies relating to the prudential supervision of credit institutions, art. 4 para. 1 lit. a), [2013] O.J. (L 287) 63.

${ }^{132}$ For an analysis and critique see Tröger supra note 24 at 83. 


\subsection{Has crowdfunding supervision been implemented in your legal order? If yes, has a supervision authority specific to this activity been established?}

There is no specific regime for the prudential supervision of crowdfunding.

\subsection{Do specific criminal law provisions exist in relation to crowdfunding? Do national measures against money laundering and terrorism financing (if they exist) apply to crowdfunding?}

There are no specific criminal law provisions with regard to crowdfunding activities.

German anti-money laundering (AML) regulation ${ }^{133}$ does not explicitly address crowdfunding platforms. GwG $\S 2$ enumerates sixteen addressees of the specific duties to prevent money laundering stipulated in the act, inter alia credit institutions, financial services providers, payment systems and investment management companies as defined in the KWG, the Payment Services Supervision Act ${ }^{134}$ and the Capital Investment Code. ${ }^{135}$ Crowdfunding platforms, which structure their business model in order not to qualify as a regulated undertaking, ${ }^{136}$ are therefore not subject to the specific anti-money laundering regulation, whereas those that operate with a bank or financial services firm authorization are immediately captured by the AML regime. If this is not the case, platforms do not come under the pertinent rules at all, because their business models do not include any other relevant activity that comes under the GwG.

\section{Obligations of parties}

\subsection{Does a specific duty to inform exist? Is this duty identical to the credit institutions' or financial intermediaries' duty to inform?}

In donation and reward-based crowdfunding, the platform incurs no specific duties to inform its customers beyond regular contract law, whereas in crowdlending and crowdinvesting more far reaching obligations apply.

\subsubsection{Crowdlending}

As a consequence of the indirect contracting model, the bank that cooperates with the platform has to fulfil the extensive disclosure obligations stipulated for consumer loans ${ }^{137}$ as prescribed in European law. ${ }^{138}$ The platform itself incurs a duty to disclose information on the specifics of its involvement and the remuneration received for it. ${ }^{139}$

${ }^{133}$ Gesetz über das Aufspüren von Gewinnen aus schweren Straftaten - Geldwäschegesetz [GwG] [Moneylaundering Act] June 23, 2017, BGBL. I at 1822, https://www.gesetze-im-internet.de/gwg_2017/GwG.pdf.

${ }^{134}$ Gesetz über die Beaufsichtigung von Zahlungsdiensten (Zahlungsdiensteaufsichtsgesetz) [ZAG] [Payment Services Supervision Act] July 17, 2017, BGBL. I at 2446, http://www.gesetze-im-internet.de/zag_2018/ZAG.pdf.

135 Kapitalanlagegesetzbuch [KAGB] [Capital Investment Code] July 4, 2013, BGBL. I at 1981, https://www.gesetze-im-internet.de/kagb/KAGB.pdf.

${ }^{136}$ For a discussion see supra Fehler! Verweisquelle konnte nicht gefunden werden.

${ }^{137}$ BGB, § 491a. For detailed description of the information duties Jan Schürnbrandt, Vor § 491 para. 4, in MünCHener KOMMeNTAR ZUM BGB, Vol. 3 (Franz Jürgen Säcker et al. eds., 7th ed. 2016); for a discussion in the context of crowdlending see Veith supra note 94 at 193; Renner supra note 7 at 268-9.

138 Directive 2008/48/EC of the European Parliament and of the Council of 23 April 2008 on credit agreements for consumers and repealing Council Directive 87/102/EEC, art. 5-7, [2008] O.J. (L 133) 66, implemented in BGB, §§ 491a, 493.

${ }^{139}$ Einführungsgesetz zum Bürgerlichen Gesetzbuche (EGBGB) [Introductory Act to Civil Code], Aug. 18, 1896, RBL. 604, Art. $247 \S 13$. 


\subsubsection{Crowdinvesting}

Funding an unseasoned business without a robust track-record is fraught with informational asymmetries between investors and founders (insiders) that typically leads to adverse selection problems. ${ }^{140}$ These are all the more serious in our context, because the likelihood of failure of the funded venture and thus a default on investors' claims is generally high in crowdinvesting. ${ }^{141} \mathrm{As}$ a consequence, information obligations vis-à-vis investors are pivotal. They can follow either from contractual obligations to inform (infra 4.1.2.1) or the prospectus requirement put forward in securities regulation (infra 4.1.2.2).

\subsubsection{Contractual obligation of platforms}

Although platforms typically do not perform the role of an investment advisor with the respective set of extensive duties ${ }^{142}$ simply because they do not recommend specific investments, ${ }^{143}$ some commentators argued that they incur contractual obligations to provide specific information to investors as an investment broker. ${ }^{144}$ The main argument for this position is that by pre-screening investments and structuring information presented to the crowd, platforms solicit trust in their superior expertise and access to information that investors rely upon. ${ }^{145}$ However, others held that platforms only advertise investments without intent to incur legally binding information obligations. ${ }^{146}$ However, the latter position is not convincing given German courts' general tendency to generously presume tacit agreements in cases where information asymmetries are striking. ${ }^{147}$ Moreover, the practice of platforms not to gather, assess and provide information is irrelevant with regard to establishing potential obligations - in fact it only amounts to neglectful behavior.

${ }^{140}$ Ronald J. Gilson, Engineering a Venture Capital Market: Lessons from the American Experience, 55 Stan. L. Rev. 1067, 1077 (2003) (describing the key problems in venture capital investing); Douglas J. Cumming \& Sofia A. Johan, Venture Capital and Private Equity Contracting An International Perspective 48-52 (2009) (showing that the features of equity claims make for lemon markets in both equity and debt financing of start-up firms because unprofitable ventures are more likely to issue equity while riskier ones have a proclivity to seek debt financing).

${ }^{141}$ C. Steven Bradford, Crowdfunding and the Federal Securities Laws, 2012 Colum. Bus. L. Rev. 1, 105; more specifically for Germany Meschkowski \& Wilhelmi, supra note 4 at 1410-11.

${ }^{142}$ An investment advisor has to provide recommendations inter alia with a view to the specific financial situation of individual investors and the characteristics of the investment, see for instance BGH, July 6, 1993, BGHZ 123, 126 (128-9); Volker Emmerich, § 311 BGB para. 101, in MüNCHENER KOMMENTAR ZUM BGB, Vol. 2 (Franz Jürgen Säcker et al. eds., 7th ed., 2016).

${ }^{143}$ However, if platforms use client data to provide recommendations derived from algorithms, for instance based on past investment behavior, they might be seen as investment advisors and incur far reaching fiduciary obligations, see Jansen \& Pfeifle supra note 17 at 1849.

144 Jansen \& Pfeifle supra note 17 at 1849; generally on the highly relevant distinction of investment advice on the one hand and investment brokerage on the other in German law, see Heinz-Dieter Assmann, Negativberichterstattung als Gegenstand der Nachforschungs- und Hinweispflichten von Anlageberatern und Anlagevermittlern, 23 ZIP 637, 648 (2002); Thomas M.J. Mölllers \& Ted Ganten, Die Wohlverhaltensrichtlinie des BAW im Lichte der neuen Fassung des WpHG - Eine kritische Bestandsaufnahme, 27 ZGR 773, 785-6 (1998).

${ }^{145}$ For these well-established, general preconditions for a tacit agreement to provide information see for instance BGH, Mar. 22, 1979, 74 BGHZ 103 (106); BGH, Mar. 4, 1987, 100 BGHZ 117 (118-9); BGH, May 13, 1993, 14 ZIP 997 (1993) BGH, Oct. 19, 2006, 27 ZIP 2221 (2006); Peter W. Heermann, \& 675 BGB para. 122, in MÜNCHENER KOMMENTAR ZUM BGB, Vol. 5/2 (Franz Jürgen Säcker et al. eds., 7th ed., 2017); Joachim Siol, § 45. Anlagevermittlung und Prospekthaftung der Banken, in: BANKRECHTS-HANDBUCH para. 6 (Herbert Schimansky et al. eds., 5th ed. 2017).

${ }^{146}$ Meschkowski \& Wilhelmi, supra note 4 at 1413

${ }^{147}$ For an analysis and critique of cases see Jörg Benedict, Die Haftung des Anlagevermittlers, 26 ZIP $2129,2131-3$ (2005) 
According to general standards, platforms therefore have an obligation to fully and correctly provide all information material for the investment decision they possess. ${ }^{148}$ Furthermore, they have to verify the plausibility of the information the initiator of the campaign supplies. ${ }^{149}$ This means, as a minimum, they have to assess whether the initiator provided all material information investors need to gauge the risks inherent in the investment (for instance on the project idea, business plan, specific risks, management, legal form of business venture and investment) and to disclose information gaps, if the initiator's submission proves insufficient and additional data is unavailable. ${ }^{150}$ Moreover, commentators argued that in a second step platforms have to roughly evaluate the viability of the venture, in order to weed-out "evidently extreme examples" of unrealistic and ludicrous business models. ${ }^{151}$

\subsubsection{Prospectus requirement}

Potentially, an important channel through which information asymmetries between issuers and investors can be countered in crowdinvesting, can follow from a prospectus requirement. Obviously, the platforms as intermediaries cannot have an original duty to draw-up a registration document themselves, but can serve as powerful gatekeepers, if the general prohibition to distribute financial instruments without prospectus ${ }^{152}$ also applies for investments initiated and concluded through crowdinvesting platforms.

Until July 10, 2015, a full blown prospectus requirement under VermAnlG, § 6 for offerings with a nominal value of more than EUR 100.000 existed, yet certain financing relationships, like in particular profit-sharing loans with subordination clauses ("partiarische Nachrangdarlehen") were generally not captured by the regime. ${ }^{153}$ The reform package of the Small Investor Protection Act ${ }^{154}$ closed the unintended loopholes, but established an exemption for financial assets offered through crowdinvesting platforms ("Schwarmfinanzierung"). ${ }^{155}$ The main preconditions ${ }^{156}$ are that the aggregate value of the offering does not exceed EUR 2,500,000, that subscription limits that depend on net worth and income of investors and range from EUR $1,000-10,000$ are respected, ${ }^{157}$ and that compliance with these preconditions is monitored by the platform. The primary source of information becomes the mandatory investment information sheet ("Vermögensanlagen-Informationsblatt"), which has to be prepared by issuers and provided to potential investors who have to confirm that they (read and) understood a specific warning that points to the risk of a total loss of the invested funds. ${ }^{158}$

148 See generally 74 BGHZ 103 (110); BGH, Feb. 16, 1981, 80 BGHZ 80 (81-2); Emmerich supra note 142 at para 127; Siol supra note 145 at para 9.

${ }^{149}$ Emmerich supra note 142 at para 127.

${ }^{150}$ Emmerich supra note 142 at para 127; Siol supra note 145 at para 9.

151 Jansen \& Pfeifle supra note 17 at 1850.

152 VermAnIG, § 18 para. 1 no. 2 and no. 3 empower the supervisor (BaFin) to prohibit public offerings of investments from going forward if they violate the prospectus requirements.

${ }^{153}$ See Meschkowski \& Wilhelmi, supra note 4 at 1415; Klöhn \& Hornuf, supra note 4 at 259; Nietsch \& Eberle, supra note 112 at 2579.

${ }^{154}$ Small Investor Protection Act [Kleinanlegerschutzgesetz, KASG], July 3, 2015, BGBL. I at 1114, art. 2 no. 4.

155 VermAnlG, § 2a.

${ }^{156}$ For a more granular description of the relevant statutory requirements, Klöhn, Hornuf \& Schilling, supra note 15 at 59-60; for in-depths analyses see Danwerth, supra note 13 at 25-36; Matthias Casper, Das Kleinanlegerschutzgesetz - zwischen berechtigtem und übertriebenem Paternalismus, 27 ZBB 265, 275-80; Nietsch \& Eberle, supra note 108 at 1789.

${ }^{157}$ For a policy discussion of investment limits see Klöhn \& Hornuf, supra note 4 at 262-4. For a critique of the current limits see Lars Klöhn \& Lars Hornuf, Die Regelung des Crowdfunding im RegE des Kleinanlegerschutzgesetzes - Inhalt, Auswirkungen, Kritik, Änderungsvorschläge, 68 DB 47, 52-53 (2015).

${ }^{158}$ VermAnIG, §§ 13, 15. For details see Klöhn, Hornuf \& Schilling, supra note 15 at 60. 
Therefore, issuers on crowdinvesting platforms have limited choice regarding the regime for primary market disclosure. ${ }^{159}$ They can either opt for a full-fledged prospectus and offer their product publicly without restrictions or accept limitations and make use of the exemption offered to crowdinvesting.

\subsubsection{Investor information sheet}

The investment information sheet is supposed to make essential information available to potential investors in a condensed manner to guide the investment decision. This also requires the explicit notice that no prospectus was prepared for the offering. ${ }^{160}$ The advertisement restrictions, to be enforced by BaFin, ${ }^{161}$ ensure that the express warnings prescribed by law, do not go missing in any other relevant communication regarding the investment. ${ }^{162}$

\subsection{Is there an obligation to guarantee accomplishment of the project? Is there an obligation to guarantee follow-up of the project?}

German law does not provide for an obligation to guarantee the accomplishment of the project or the participation in follow-up projects. However, typical contractual arrangements contain all-or-nothing clauses that ensure that initiators will only draw on individual contributions if the campaign reaches the target volume of financing. ${ }^{163}$ Hence, contributors have at least some certainty that the preconditions for successfully initiating the project are met. Moreover, some protections against abusive practices ex post exist, most importantly the obligation to pay damages if the initiator misappropriates the funds received. ${ }^{164}$

\subsection{Is there an obligation of payment of the collected funds?}

In Germany, platforms carefully avoid collecting funds due to regulatory implications (see supra 3.1.1). As a consequence, no such obligation exist, but the design of crowdfunding transactions typically ensures that funds reach the campaigns' beneficiaries (supra 4.2).

\subsection{Are the platforms subject to any other duties which are not mentioned above?}

There are no other material obligations for platforms.

159 On the concept see Roberta Romano, Empowering Investors: A Market Approach to Securities Regulation, 107 YALE L.J. 2359, 2362, 2418 (1998) (proposing that issuers be permitted to opt into both US States' and foreign nations disclosure regimes); Alan R Palmiter, Toward Disclosure Choice in Securities Offerings, 1999 COLUM. BuS. L. REV. 1, 86-91 (restricting issuer choice to the selection of a primary market disclosure regime); for a critique see Merritt B. Fox, Retaining Mandatory Securities Disclosure: Why Issuer Choice is not Investor Empowerment, 85 VA. L. REV. 1335, 1345-56 (1999) (holding that the divergence between managers' private benefits and social benefits derived from disclosure rules will induce suboptimal outcomes under a regime of issuer choice).

160 VermAnlG, § 13 para. 3a.

${ }^{161}$ VermAnIG, § 16 para. 1; see Klöhn, Hornuf \& Schilling, supra note 15 at 60.

162 VermAnIG, $\S 12$ para. 2 and 3 prescribe that the express warnings that a total loss of funds invested is possible and that a promised return is not guaranteed are sufficiently visible also in advertisement campaigns. For a granular delineation of the restrictions see Gerd Waschbusch, Die Masse macht's - Crowdfunding al Finanzierungsmöglichkeit für Existenzgründer, 67 DER STEUERBERATER (STB) 206, 208 (2016).

163 Jansen \& Pfeifle supra note 17 at 1844; Bareiß supra note 20 at 459 (reporting that payment accounts of contributors are only debited if target levels for overall financing are reached or contributions are returned if these levels are undercut).

${ }^{164}$ At least the general duty to avoid any acts that threaten the purpose parties pursue with the contract (on the respective construction of the accompanying duties mentioned in BGB, § 241 para. 2 see Gregor Bachmann, \& 241 para. 85, in MüNCHENER KOMMENTAR ZUM BGB, Vol. 2 (Franz Jürgen Säcker et al. eds., 7th ed., 2016) applies, regardless of the legal qualification of the crowdfunding relationship. See Jansen \& Pfeifle supra note 17 at 1845 note 21,1846 without doctrinal specification. See also infra 4.16. 


\subsection{In your legal order, what are the duties of the project directors towards the plat- form and towards the contributor?}

The obligations of project directors towards the platform are determined by the classification of the contractual relationship between platforms and initiators of crowdfunding campaigns. As the platform assumes a brokering role, the contractual relationship is commonly understood as an agency contract ("Maklervertrag"). ${ }^{165}$ Therefore, under the default rule, ${ }^{166}$ project directors are only liable for fees if the platform actually provides the opportunity to conclude contracts with contributors.

The duties of directors towards contributors are determined by the nature of the contractual relationship (supra 1.3). In crowdsponsoring, this means that the beneficiary assumes no primary obligation vis-à-vis contributors, but has to honor the expectations of the donors as part of its bona fide obligations. ${ }^{167}$ In reward based crowdfunding transactions, the initiator has to produce the good (merchandise, movie, music etc.) to be able to provide contributors with (preferential) access. In crowdlending, the primary obligation is to pay the agreed interest rate and redeem the loan at maturity. In both cases, the bona fide duties also apply and limit the leeway for initiators to deviate from the original plans (see also infra 4.16). Finally, as typical crowdinvestment transactions are also structured as debt contracts (supra 1.3.4), the primary obligation of project directors is to pay the agreed remuneration (profit participation) and redeem the principal amount.

In practice, these principal obligations of project directors are specified and modified in the standard terms and conditions, with the BGB's default rules providing the backdrop for a judicial evaluation of the validity of these deviations. ${ }^{168}$

\subsection{Do specific provisions protecting the reality and integrity of the contributor's con- sent exist?}

Protections beyond general contract law flow from the provisions on standard terms ${ }^{169}$ and on consumer credit. ${ }^{170}$ While the law on standard terms requires that platforms make all respective contractual terms readily available before the contract is concluded, ${ }^{171}$ the law on consumer credit provides for a withdrawal right in a cooling-off period post contracting. ${ }^{172}$

Moreover, with regard to crowdinvesting, contributors benefit from a specific regime aimed at protecting their freewill. ${ }^{173}$ Potential investors have to explicitly confirm, either by a dated and located signature with their full name or - if the contract was negotiated and concluded exclusively by means of distance communication - with an equivalent electronic identification, that they took notice of the warnings included in the investment information sheet (supra 4.1.2.3). ${ }^{174}$

${ }^{165}$ For crowdinvesting Jansen \& Pfeifle supra note 17 at 1851 (also showing that platforms are not commercial agents).

166 BGB, § 652 .

${ }^{167}$ As outlined supra note 164 under German law, every obligation carries the accompanying duty to avoid any act that could thwart the contractual goals of the other party.

${ }^{168}$ BGB, $\S 307$ para. 2 s. 1. On impact this provision that reinforces the equitable content of default rules see Wolfgang Wurmnest, $\S 305$ para. 65, in MüNCHENER KOMMENTAR ZUM BGB, Vol. 2 (Franz Jürgen Säcker et al. eds., 7th ed., 2016).

169 BGB, §§ 305-310.

$170 \mathrm{BGB}, \S \S 491-505 \mathrm{e}$.

171 BGB, §§ 305 para. 2.

172 BGB, § 495.

${ }^{173}$ For a detailed description see Klöhn, Hornuf \& Schilling supra note 15 at 60; Casper supra note 156 at 279 .

${ }^{174}$ VermAnlG, $\S 15$ paras. 3 and 4. 


\subsection{What are the duties of a lender (contributor by means of a loan)?}

In the indirect contracting model preferred by German crowdlending platforms, the contributor acquires the repayment claim against the borrower in a purchase from the bank or an entity that collaborates with the platform (see supra 1.3.3). The duty to provide the funds ultimately extended to the borrower thus results from a sales contract with the loan originating bank or the service firm collaborating with the platform.

In general, German courts have been reluctant to impose any additional duties on lenders regarding the use of the funds provided to the borrower. ${ }^{175}$ However, if the loan is originally provided by a bank, as is the case in the indirect contracting model, the financial institution has to assess the borrower's creditworthiness (responsible lending). ${ }^{176}$

\subsection{Is the loan subject to the law on usury (if relevant)? Are there any rules about the interest rate determination? Are there any rules about the length of the loan?}

The rules on usurious loans apply as part of general contract law. ${ }^{177}$ There are no specific rules on either the determination of the interest rate or the loan's maturity in crowdlending/-investment. Typically, these parameters are either pre-set by crowdlending platforms or determined in an auction. ${ }^{178}$

\subsection{What are the duties of a donator (contributor by the means of donation)?}

There is no other primary obligation for a donor than to make the agreed gratuitous contribution. Of course, secondary obligations of good faith attach under general contract law. ${ }^{179}$ However, they do not seem to have a specific application with regard to donors in crowdsponsoring transactions.

\subsection{Is the donation subject to specific formal validity rules? Is there a maximum amount per project for the donation made by one donator? What can a project director receive?}

A promise to donate has to be notarized in order to be legally binding. ${ }^{180}$ However, if the contribution is actually made, the formal deficit is cured. ${ }^{181}$ Moreover, if the donation is immediately executed, i.e. not preceded by a promise executed later down the road, the underlying contractual relationship is also valid from the outset. ${ }^{182}$

\subsection{Do money laundering provisions apply to this activity?}

Individual contributors as such are not subject to AML regulations as they are not addressees of the respective provisions (see supra 3.5).

175 For the general rule see BGH, Apr. 3, 1996, 49 NJW 1206, 1207 (1996).

176 BGB, §§ 505a-505e.

177 BGB, $\S 138$. For an overview of the complex jurisprudence that presumes a relevant mismatch if the interest rate charged is two times as high as the relevant basis rate see BGH, Jan. 15, 1987, BGHZ 99, 333 (336); Christian Armbrüster, § 138 BGB para. 119, in MüNCHENER KOMMENTAR ZUM BGB, Vol. 1 (Franz Jürgen Säcker et al. eds., 7th ed., 2016).

178 Renner supra note 7 at 263.

179 BGB, §§ 241 para. 2, 242.

180 BGB, § 518 para. 1 s. 1.

${ }^{181} \mathrm{BGB}, \S 518$ para. 2.

182 The notarization requirement seeks to prevent hasty decision making that does not properly reflect the transfer of value, which seems unnecessary if the instantaneous transfer of property makes the sacrifice immediately felt, see for instance Koch supra note 29 at $\S 518$ para. 1; Chiusi supra note 29 at $\S 518$ para. 1. 


\subsection{What are the duties of a buyer (contributor by the means of anticipated purchase of goods or services)?}

There is no other primary obligation for a buyer than to pay the agreed purchase price and (physically) accept the delivered merchandise. Once again, secondary obligations of good faith attach (supra 4.9).

\subsection{Is the buyer limited by a maximum amount of the purchase? Are there any formal validity conditions?}

As a matter of law, there are no restrictions like a maximum amount of goods available or a maximum price for purchases chargeable in reward based crowdfunding.

There are no formal validity conditions for typical reward-based crowdfunding transactions.

\subsection{What are the duties of a contributor buying equity in a company?}

Crowdinvesting campaigns that solicit contributions through hybrid capital instruments (supra 1.3.4) aim at mimicking negotiable instruments in public capital markets. Hence, duties of investors that contribute are limited to supplying the agreed amount of capital for the stipulated duration of the transaction. ${ }^{183}$

\subsection{Is there a maximum amount for an equity contribution? What is the legal nature of the counterpart? (shares? corporate bonds?)}

The safe harbor provided in securities regulation with regard to primary market disclosure (supra 4.1.2.2) provides a strong incentive to limit and monitor individual subscriptions in crowdinvesting campaigns. However, these limits are not legally binding if issuers chose to provide prospectuses for their offerings.

As outlined above, crowdinvesting typically occurs through hybrid debt contracts, mainly profit participating subordinated loans (supra 1.3.4).

\subsection{In case of non-accomplishment of the project, is there any redress mechanism against the project director or against the platform?}

The simple failure of a crowdfunding project as such does not give rise to any redress, because neither platforms nor project initiators guarantee the success of the venture (supra 4.2). Only if the failure is due to the breach of a specific contractual obligation and there is a finding of fault on the side of the party in breach, damages may be available. ${ }^{184}$

Platforms as brokers of crowdfunding relationships typically have no duties in relation to the execution of the project as such. However, they can be liable for a breach of an obligation to inform. Such duties are most prominent in crowdinvesting where platforms may assume a role as investment brokers subject to specific information obligations (supra 4.1.2.1), with a rich body of case law specifies. ${ }^{185}$

Fraudulent behavior aside, project directors may be liable if they deploy funds in a way that contradicts the project description in the campaign. This can amount either to a breach of the primary obligation to produce a certain good (reward based crowdfunding) or violate the secondary obligation

183 For details on market standards regarding maturity etc. see supra 1.3.4.

184 BGB, §§ 280 para. 1, 276 para. 1.

185 The cases do not specifically pertain to crowdinvesting, but to investment brokers in general and are therefore relevant for the determination of platforms' duties to inform. For an overview see Siol supra note 145 at para. $18-21$. 
to avoid any action that imperils the other party's contractual objectives (crowdsponsoring, crowdinvesting). ${ }^{186}$ At the margin, this requires difficult distinctions whether a deviation from the original plans was a good faith attempt to achieve the original goals of the crowdfunding campaign or a misappropriation of funds.

In principle, unsound managerial decisions that are not in line with acceptable business practice can give rise to liability. ${ }^{187}$ However, although no specific case law is available (see infra 7.1), courts will probably be reluctant to find fault in business decisions, as long as they were made on a sound informational basis and in the absence of conflicts of interest. ${ }^{188}$

\subsection{Have specific mechanisms been implemented against fraudulent behaviour?}

There are no crowdfunding specific mechanisms to prevent fraud in German law.

\section{Crowdfunding platforms}

\subsection{What is the currency used by the platforms for their activities on the territory of your legal order? Is it possible to use a foreign currency?}

Platforms solicit contributions in euros. There are no legal restrictions on using foreign currency. ${ }^{189}$

\subsection{To the extent that the platform allows cross-border activity, what is the percent- age of the collected funds intended to be transferred to a State other than the one where the platform's company is located?}

There is no reliable aggregate data available on this question for the German crowdfunding market.

\subsection{Are the terms of use of crowdfunding platforms easily accessible?}

The terms of crowdfunding platforms are available on their websites and have to be made accessible to individual clients before contracting as a matter of law (see supra 4.6).

\subsection{Do the terms of use contain choice of forum clauses? choice-of-law clauses? arbi- tration clauses?}

While both choice of forum and choice of law clauses are common, ${ }^{190}$ arbitration clauses are atypical.

\subsection{In your country, does a crowdfunding platforms' professional association exist? If yes, could you indicate its website and when it started its activity?}

The German Crowdfunding Association ("Bundesverband Crowdfunding") was established on Nov. 4, 2015 and entertains a website at http://www.bundesverband-crowdfunding.de/.

186 See already supra note 164 .

187 To find negligence, BGB, § 276 para. 2, requires a showing that the debtor violated the duty of care as observed by the respective public circles. Hence, the objective standard needs to be specified with a view to the respective contractual obligation, see for instance BGH, Mar. 17, 1981, BGHZ 80, 186 (193); Stefan Grundmann, § 276 BGB para. 55-6, in MünCHENER KOMMENTAR ZUM BGB, Vol. 2 (Franz Jürgen Säcker et al. eds., 7th ed., 2016).

${ }^{188}$ An explicit safe harbor protecting business judgement against judicial second guessing prone to hindsight bias is codified in AktG, § 93 para. 1 s. 2 for managers of stock corporations. Beyond the narrow scope of this specific provision, the underlying principle is also relevant in general private law.

${ }^{189} \mathrm{Cf}$. BGB, § 244 presumes that parties to a contract can agree on the use of any currency, for details see Stefan Grundmann, $\S \S 244,245$ BGB paras. 88-98, in MüNCHENER KOMMENTAR ZUM BGB, Vol. 2 (Franz Jürgen Säcker et al. eds., 7th ed., 2016).

${ }^{190}$ Spindler supra note 81 at 139 note 144. 


\subsection{Have the crowdfunding platforms established a professional code of ethics?}

The German Crowdfunding Association has established a code of conduct for its members. ${ }^{191}$

\section{Tax Measures}

\subsection{How are the contributions taxed in your country?}

There is no specific tax regime for crowdfunding. Therefore, contributions are treated under the general provisions of the income and corporate tax codes. ${ }^{192}$

On the side of the contributor, the main aspect for tax purposes is the treatment of returns flowing from the contribution. The latter as such is largely irrelevant for tax purposes - except for certain donations (see infra 6.2) - because it constitutes a simple exchange of assets in the contributor's private estate or on its corporate balance sheet. If the crowdfunding contribution generates returns in the form of interest rate payments (crowdlending), profit participations or capital gains (crowdinvesting), the returns are taxed as income from capital. For natural persons acting in a private capacity this means that their relevant income is subject to a flat rate withholding tax of $25 \%{ }^{193}$ and an additional solidarity surcharge of $5.5 \%$ of the income tax due. ${ }^{194}$ Where the investor acts in a commercial capacity, the returns from fixed interest loans, profit participation rights or profit participating loans (see supra 1.3.3 and 1.3.4) are taxed with the investor's personal tax rate and a 5.5\% solidarity tax; where the investor is a corporation, the respective returns are subject to $15 \%$ corporate income tax and the $5.5 \%$ solidarity tax add-on. ${ }^{195}$

If the beneficiary is a corporation, it will book the contribution on its tax balance sheet - in crowdlending and crowdinvesting transactions as debt - without any immediate tax impact. The interest rate paid or the profit participation granted represent deductible operating expenses. ${ }^{196}$

\subsection{Do the contributors benefit from a tax exemption in relation to their contribution?}

Contributors can only benefit from tax exemptions if their donations go to recipients that tax authorities recognized as charitable organizations. ${ }^{197}$

191 Bundesverband Crowdfunding, Verhaltenskodex für Crowdfunding-Plattformen im Bundesverband Crowdfunding e.V. (2018), http://www.bundesverband-crowdfunding.de/verhaltenskodex-fuer-crowdfundingplattformen-im-bundesverband-crowdfunding-e-v/.

192 For an overview of the tax treatment of crowdinvestment, with a specific view on the treatment of returns see, Stefan Rogge, Überblick über die Besteuerung von Crowdinvestments, 72 BB 31 (2017).

${ }^{193}$ For details see Einkommensteuergesetz (EStG) [Income Tax Code], §§ 20 para. 1 No. 1, No. 4 and No. 7, para. 2 s. 1 No. 1, 32d para. 1, Oct. 8, 2009, BGBI. I at 3366, 3862. If the individual tax rate is lower, contributors can seek reimbursement of the difference in their income tax declaration.

194 Solidaritätszuschlagsgesetz 1995 (SolzG 1995) [Solidarity Tax Act 1995], §§ 1 para. 1, 4 s. 1, Oct. 15, 2002, BGBL. I 4130.

${ }^{195}$ For details see Rogge supra note 192 at 33-34. The significant tax exemption granted in Körperschaftssteuergesetz (KStG) [Corporate Tax Code], § 8b, Oct. 15, 2002, BGBI. I at 4144, does not apply to the typical forms of crowd-funding investments, because the hybrid capital instruments granted in campaigns (supra 1.3.4) do not qualify as an equity stake for tax purposes.

196 Rogge supra note 192 at 33-34 (also explaining the complicated regime of local business tax).

197 EStG, § 10b para. 1; KStG, § 10b para. 1 No. 2. 


\section{Litigation}

7.1 Are there closed or still ongoing proceedings in relation to crowdfunding? If yes, who started the proceedings? What was the matter of the case(s)? Was the jurisdiction of the court challenged because of a cross-border dimension of the case?

According to publicly available information, there are neither closed nor ongoing proceedings in relation to crowdfunding.

\subsection{Are you aware of any arbitration proceeding in relation to the crowdfunding activ- ity?}

I'm not aware of any arbitration proceeding in relation to crowdfunding activity.

\subsection{Do specific actions (class actions?) exist for disputes in relation to crowdfunding activity?}

No specific actions (class actions) exist for disputes in relation to crowdfunding activity.

\section{Miscellaneous}

8.1 If there are any points you would like to develop which were not dealt with by this questionnaire, please feel free to add your comments below. $\mathrm{n} / \mathrm{a}$

8.2 Could you please mention below the main articles relating to the legal regulation of crowdfunding in your country?

- Lars Klöhn \& Lars Hornuf, Crowdinvesting in Deutschland, 24 ZEITSCHRIFT FÜR BANKRECHT UND BANKWIRTSCHAFT (ZBB) 237 (2012)

- Lars Klöhn, Lars Hornuf \& Tobias Schilling, Regulation of Crowdfunding in the German Small Investor Protection Act: Content, Consequences, Critique, Suggestions, 13 EUR. CoMP. L. 56 (2016)

- David Jansen \& Theresa Pfeifle, Rechtliche Probleme des Crowdfunding, 33 ZEITSCHRIFT FüR WIRTSCHAFTSRECHT (ZIP) 1842 (2012)

- Alexander Meschkowski \& Frederike K. Wilhelmi, Investorenschutz im Crowdinvesting, 68 BETRIEBS-BERATER (BB) 1411 (2013)

- Moritz Renner, „Banking Without Banks“? Rechtliche Rahmenbedingungen des Peer-to-Peer Lending, 26 ZBB 261 (2014)

- Gerald Spindler, Crowdfunding und Crowdinvesting -Sach- und kollisionsrechtliche Einordnung sowie Überlagerung durch die E-Commerce-Richtlinie, 29 ZBB 129 (2017)

- Julian Veith, Crowdlending - Anforderungen an die rechtskonforme Umsetzung der darlehensweisen Schwarmfinanzierung, 16 ZEITSCHRIFT FÜR BANK- UND KAPITALMARKTRECHT (BKR) 184 (2016) 


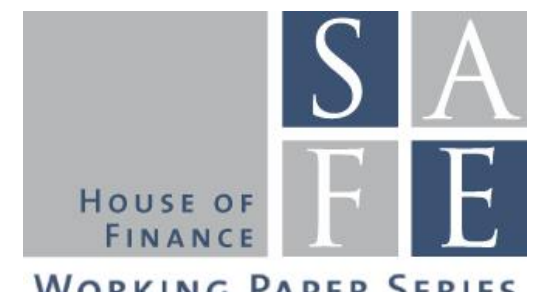

Working PAPER SERIES

\section{Recent Issues}

No. 198 Henning Hesse, Boris Hofmann, James Weber

No. 197 Benjamin Clapham, Peter Gomber, Martin Haferkorn, Paul Jentsch, Sven Panz

No. 196 Benjamin Clapham, Peter Gomber, Sven Panz

No. 195 Benjamin Clapham, Peter Gomber, Martin Haferkorn, Sven Panz

No.194 Baptiste Massenot

No. 193 Mario Bellia, Roberto Panzica, Loriana Pelizzon, Tuomas Peltonen

No. 192 Vincenzo Pezone

No. 191 Julia Hirsch, Uwe Walz

No. 190 Vanya Horneff, Raimond Maurer, Olivia S. Mitchell

No. 189 Carlo Wix

No. 188 Michael Donadelli, Patrick Grüning, Marcus Jüppner, Renatas Kizys

No. 187 Baptiste Massenot, Yuri Pettinicchi

No. 186 Nicole Branger, Paulo Rodrigues, Christian Schlag
The Macroeconomic Effect of Asset

Purchases Revisited

Circuit Breakers - A Survey among International Trading Venues

Coordination of Circuit Breakers? Volume Migration and Volatility Spillover in Fragmented Markets

Managing Excess Volatility: Design and Effectiveness of Circuit Breakers

A Business Cycle Model with Neuroeconomic Foundations

The Demand for Central Clearing: To Clear or Not to Clear, That is the Question

The Real Effects of Judicial Enforcement: Evidence from Italy

Financial constraints, newly founded firms and the financial crisis

How Persistent Low Expected Returns Alter Optimal Life Cycle Saving, Investment, and Retirement Behavior

The Long-Run Real Effects of Banking Crises: Firm-Level Investment Dynamics and the Role of Wage Rigidity

Global Temperature, R\&D Expenditure, and Growth

Can Firms see into the Future?

Survey evidence from Germany

Level and Slope of Volatility Smiles in LongRun Risk Models 